2019-04-15

\title{
Silicon isotopic systematics of deep-sea sponge grounds in the North Atlantic
}

\author{
Hendry, KR
}

http://hdl.handle.net/10026.1/14573

10.1016/j.quascirev.2019.02.017

Quaternary Science Reviews

Elsevier

All content in PEARL is protected by copyright law. Author manuscripts are made available in accordance with publisher policies. Please cite only the published version using the details provided on the item record or document. In the absence of an open licence (e.g. Creative Commons), permissions for further reuse of content should be sought from the publisher or author. 
2 Katharine R. Hendry ${ }^{1}$, Lucie Cassarino ${ }^{1}$, Stephanie L. Bates ${ }^{1}$, Timothy Culwick ${ }^{1}$, Molly Frost ${ }^{1}$, Claire Goodwin², Kerry L. Howell

${ }^{1}$ School of Earth Sciences, University of Bristol, Wills Memorial Building, Queen's Road, Bristol BS3 $1 \mathrm{NH}$, United Kingdom

$6{ }^{2}$ Huntsman Marine Science Centre, 1 Lower Campus Rd, Saint Andrews, New Brunswick, E5B 3A3, $7 \quad$ Canada

$8{ }^{3}$ School of Biological and Marine Sciences, Plymouth University, Drake Circus, Plymouth, PL4 8AA, 9 United Kingdom

Keywords: Porifera, isotopes, silicic acid, geochemical archives

\section{Abstract}

Reconstruction of silica cycling in the oceans is key to a thorough understanding of past climates because of the inherent links between the biogeochemistry of silicifiers and sequestration of organic carbon. Diatoms are one of the most important phytoplankton groups in determining export production from surface waters, and rely largely on upwelling deeper waters as a source of dissolved silicon, an essential nutrient for their growth. Quantification of changes in deep water dissolved silicon concentrations in the past allows a more robust understanding of changes in surface nutrient supply and whole-ocean silicon cycling, but cannot be achieved using surfacederived geochemical archives. In the last few years, there has been increasing focus on the use of geochemical archives in siliceous skeletal elements, or spicules, from seafloor-dwelling sponges to fill this gap. The stable silicon isotopic composition of spicules has been shown to be a function of ambient dissolved silicon, providing a potential archive for past changes in bottom water nutrients. However, biomineralisation processes impact silicon isotope fractionation and silica formed by atypical processes (derived from carnivorous sponges, hypersilicified spicules, and giant basal spicules) result in anomalous geochemical signatures. Furthermore, there is considerable scatter in the calibration between spicule silicon isotopes and dissolved silicon in seawater, even when the atypical groups have been removed. Here, we explore this variability further, by examining aggregation and assemblage-level differences in isotopic fractionation, using silicon isotopic measurements of specimens from two monospecific sponge groups (Pheronema carpenteri and 
Vazella pourtalesi), and one mixed-species population (genus Geodia) from the North Atlantic. Our new data reveal that variability within the monospecific aggregations is less than mixed-species assemblage, pointing towards a genetic control in isotopic fractionation. However, there is still variability within the monospecific aggregations, which cannot be explained by macroscale environmental differences: such variability is likely a reflection of the physiological health of the individuals, or highly localised heterogeneities in sponge habitats.

Other challenges remain in the interpretation of spicule silicon isotopes as proxies for dissolved silicon changes through time, especially when investigating periods of Earth history that extend back considerably further than the residence time of dissolved silicon in the oceans. Despite all the questions still surrounding the use of sponge silicon isotopes in palaeoceanographic applications, they are still the only known archive of bottom water dissolved silicon. Continued efforts to understanding sponge biomineralisation and to incorporate silicon isotopes into oceanic models will help to improve further the reliability of the archive.

\section{Introduction}

\subsection{The marine silicon cycle: why study the deep?}

The marine biological pump plays a key role in the carbon cycle, through the uptake of carbon from the atmosphere $\left(\mathrm{CO}_{2}\right)$ during algal growth and subsequent sequestration of carbon via the burial of organic matter at depth. The majority of marine production, occurring away from direct inputs of nutrients, is supported by upwelled nutrients supplied through the remineralisation of sinking particles or release from seafloor sediments. Diatoms, a photosynthetic algae, are responsible for a significant proportion, up to $40 \%$, of primary production in the oceans (Tréguer et al., 2018). Their absolute requirement for dissolved silicon (DSi, in the form of silicic acid) to build their silica tests or frustules, means that there is a fundamental link between both the cycling of silicon and carbon within the climate system (first described by DeMaster, 1979; more recently reviewed by Tréguer and De la Rocha, 2013). The robust quantification of DSi within deep and upwelling waters through time is essential if we are to understand the growth of diatoms in the surface of the world's oceans, the drawdown of $\mathrm{CO}_{2}$, and the burial of organic matter (Hendry and Brzezinski, 2014).

In addition to diatoms, there are a wide range of other organisms that precipitate DSi from seawater (silicifiers) including bacteria (Baines et al., 2012), other single-celled eukaryotes (e.g. radiolarians, silicoflagellates, choanoflagellates, some haptophytes, plants, and animals (Hendry et al., 2018; Marron et al., 2016)). Sponges are the most significant group of animals that contribute to 
the marine silicon cycle, because the phylum contains a number of silicifying groups requiring a large supply of DSi to form their skeletal elements, or spicules. Unlike diatoms, sponges are seafloordwelling and obtain the required DSi from bottom waters rather than surface waters. Given the cosmopolitan distribution of sponges and the high preservation potential of siliceous spicules (Maldonado et al., 2011; Schrader, 1972), they may possibly form a substantial standing stock of sedimentary biogenic silica (BSi) in some continental shelf regions (Maldonado et al., 2011), but will also provide an important archive of the geochemical signature of bottom waters. The occurrence of sponge spicules, over the entire Phanerozoic (Antcliffe et al., 2014), has led to their investigation as potentially useful archives of past oceanic change, especially for deep-water DSi through time (De La Rocha, 2003).

\subsection{Aims of this review}

Given the reliance of diatoms, and other surface-dwelling silicifiers, on upwelling supplies of DSi, there is substantial motivation to understand the geochemical signatures recorded in marine sponges, which could act as palaeoceanographic proxies for past changes in marine silicon cycling. The silicon isotope composition (denoted by $\delta^{30} \mathrm{Si}$ ) of sponges has shown promise as a proxy for past bottom-water $\mathrm{DSi}$, due to the discovery of a statistically significant correlation between sponge silicon isotopic fractionation and ambient DSi (Hendry et al., 2010; Wille et al., 2010). Here, we review the developments in the understanding of silicon isotope fractionation by sponges during spicule formation, including recent studies highlighting anomalous fractionation during some forms of biomineralisation, and their use in palaeoceanographic studies. We will present new $\delta^{30} \mathrm{Si}$ data investigating populations of sponges from North Atlantic sponge grounds, specifically to assess variation in isotopic composition of individuals from mono-specific aggregations and multi-specific assemblages. Variation between these individuals, which have grown under almost identical environmental conditions, can be used to address physiological impacts (e.g. growth rate, food supply, health) on spicule $\delta^{30} \mathrm{Si}$ compositions, and the potential impact of these biogeochemically important grounds on the use of spicules as geochemical archives. Finally, we will use our new data together with published data in the literature to re-evaluate the $\delta^{30} \mathrm{Si}$-DSi calibration.

\section{Sponges as geochemical archives}

\subsection{Sponge silicification: the role of enzymatic processes}

Sponges are predominantly filter-feeding benthic animals (Phylum Porifera), with an ancestral body plan comprising a gelatinous mesohyl surrounded by two layers of cells. Water is circulated throughout the body via a series of pores in an aquiferous "canal" system, aided by 
flagellated choanocyte cells. Other cells have specialised and changeable functions, including reproduction, digestion, collagen production, and spicule formation. Spicules are produced from carbonate, proteins, or BSi in the case of Classes Demospongea, Homoscleromorpha, and Hexactinellida. These siliceous structures are highly diverse in their morphology, and are produced in - at least initially - and assembled in specialised sclerocytes before being exported out of the cell, where silicification is completed. Spicules can be separated, joined at nodes, or fused by secondary silica (Hooper and Van Soest, 2002). Despite being of great interest for biomaterials research (Jo et al., 2016), the biochemical pathways involved in spicule silicification are not fully understood. Silicification in sponges is generally considered to be controlled by two enzymes: silicatein, which promotes polycondensation reactions, and silicase, which dissolves silica (Müller et al., 2013; Müller et al., 2007; Schroeder et al., 2003). Most spicules are formed in layers around a central filament of silicatein (Shimizu et al., 1998), resulting in a central "axial" canal structure in the final form. However, molecular data suggest the enzymes involved in silicification may have evolved independently multiple times, occurring in individuals that do not express the silicatein gene, and may have been lost as a trait in some non-silicifying lineages (Riesgo et al., 2015).

Regardless of the specific biochemical pathway, DSi is a requirement for silicification, and DSi availability is an important factor in determining the distribution of sponges in the oceans (Howell et al., 2016). The uptake of DSi is regulated by availability, and growth experiments in laboratory-cultured sponges reveal that there is a Michaelis-Menten relationship between uptake and DSi concentration, indicative of enzymatic control (López-Acosta et al., 2018; López-Acosta et al., 2016; Maldonado et al., 2011; Reincke and Barthel, 1997). For some shallow-water species, such experiments have shown that significant uptake only occurs when DSi concentrations far exceed natural ambient conditions, which has led to the proposition that these sponges suffer chronic silicon limitation (Maldonado et al., 2012). The measured kinetic parameters vary both between and within species, indicating both an evolutionary control on the nature and functioning of these enzymes, in addition to an influence of physiological factors such as food availability and health on DSi uptake (López-Acosta et al., 2016).

\subsection{Silicon isotopes in sponges}

Sponge biogenic silica is relatively pure, with a general formula $\mathrm{SiO}_{2} \cdot \mathrm{nH}_{2} \mathrm{O}$, with a greater and more variable degree of hydration relative to diatom silica. Given the trace abundance of incorporated metals, the majority of proxy calibration studies have focused on the use of silicon isotopes as geochemical tracers, although there have been some studies into the use of some trace elements and their isotopes e.g. zinc and germanium (Guillermic et al., 2017; Hendry and Andersen, 
2013). Oxygen isotopes in spicules have been the focus of a small number of studies, and appear to exhibit a high degree of variability, which is not yet mechanistically understood (reviewed in Hendry et al., 2015).

Silicon has three stable isotopes $\left({ }^{28} \mathrm{Si},{ }^{29} \mathrm{Si}\right.$ and $\left.{ }^{30} \mathrm{Si}\right)$, and fractionation of these isotopes occurs in natural systems as a result of physical, chemical or biochemical reactions. The silicon isotopic composition ( $\delta^{30} \mathrm{Si}$, Equ. 1) of spicules, and the associated fractionation of silicon with respect to seawater (denoted by $\Delta^{30} \mathrm{Si}$, Equ. 2), is highly variable (Hendry et al., 2010; Wille et al., 2010) and under certain conditions can be greater than fractionation observed for other silicifiers such as diatoms or radiolarians (Abelmann et al., 2015; Hendry et al., 2014).

$\delta^{30} S i=\left\{\left[\left(\frac{{ }^{30} S i}{{ }^{28} S i}\right)_{\text {sample }} /\left(\frac{{ }^{30} S i}{{ }^{28} S i}\right)_{N B S 28}\right]-1\right\} \times 1000$

$\Delta^{30} S i=\delta^{30} S i_{\text {sponge }}-\delta^{30} S i_{\text {seawater }}$

Although sponge $\delta^{30} \mathrm{Si}$ values were measured for the first time in the 1980s (Douthitt, 1982), spicule silicon isotopes were first postulated as a potential archive of seawater chemistry decades later (De La Rocha, 2003). Later studies of modern filter-feeding sponges (both hexactinellid and demosponges) revealed a statistically significant non-linear relationship between $\delta^{30} \mathrm{Si}$ (and $\Delta^{30} \mathrm{Si}$ ) and ambient DSi concentrations in Southern Ocean sponges (Hendry et al., 2010; Hendry et al., 2011; Wille et al., 2010), and in core-top spicules and living sponges from the Atlantic and Pacific Oceans (Hendry and Robinson, 2012) (Fig. 1). The same relationship between $\delta^{30} \mathrm{Si}$ and DSi was found in sponges from the different ocean basins, despite growing in contrasting temperature, salinity and $\mathrm{pH}$ conditions, without any systematic difference between hexactinellid and demosponges, suggesting that DSi availability is the main driving factor behind $\delta^{30}$ Si variability in sponges (Hendry \& Robinson, 2012). The $\delta^{30} \mathrm{Si}$-DSi relationship is thought to derive from the similar non-linear dependence of sponge growth rate on DSi availability (Hendry and Robinson, 2012; Wille et al., 2010), where the silicon isotopic fractionation can be expressed following Milligan et al. (2004), according to Equ. 3.

$\Delta \delta^{30} S i \approx \varepsilon_{f}=\varepsilon_{t I}+\left(\varepsilon_{p}-\varepsilon_{t E}\right) \frac{v_{E}}{v_{I}}$ where $\varepsilon_{\mathrm{f}}=$ the total Si isotopic fractionation factor, $\varepsilon_{\mathrm{tl}}=$ Si isotopic fractionation due to transport into the cell, $\varepsilon_{\mathrm{p}}=\mathrm{Si}$ isotopic fractionation due to polymerisation and $\varepsilon_{\mathrm{tE}}=\mathrm{Si}$ isotopic fractionation due to transport out of the cell; $v_{E}=$ rate of $S i$ efflux and $v_{1}=$ rate of $S i$ influx. This equation can be rearranged (Equ. 4-5, Wille et al., 2010): 
$160 \quad \varepsilon_{f}=\varepsilon_{t I}+\Delta \varepsilon_{p}\left\{1-\frac{\frac{v_{\max } p}{\left(\frac{K_{m p}}{[D S i]}\right)+1}}{\frac{v_{\max }}{\left(\frac{K m I}{[D S i]}\right)+1}}\right\}$

$K_{m I}=v_{\max I} \times \frac{K_{m p}}{v_{\max p}}$

162

where $\Delta \varepsilon_{\mathrm{p}}=\left(\varepsilon_{\mathrm{p}}-\varepsilon_{\mathrm{tE}}\right) ; \mathrm{K}_{\mathrm{ml}}$ and $\mathrm{K}_{\mathrm{mp}}$ are the half saturation constants for DSi incorporation and silica precipitation respectively, and $v_{\max }$ and $v_{\max }$ are the maximum incorporation and precipitation rates respectively. This relationship was used to reconstruct the general behaviour of silicon isotopic fractionation by filter-feeding sponges, lending strength to the hypothesis that this fractionation is driven by enzymatic processes within sclerocytes (Hendry and Robinson, 2012; Wille et al., 2010).

More recent work has highlighted that this simple non-linear relationship can breakdown when distinct biomineralisation processes are active within different groups of sponges. For example, carnivorous sponges (Vacelet, 2006) that are currently classed in the family Cladorhizidae (Order Poecilosclerida) are thought to have different isotopic systematics compared to the more ancestral body forms. Cladorhizids secondarily evolved the carnivorous habit as an adaptation to low-nutrient conditions (Vacelet and Duport, 2004), and have abandoned the ancestral body organisation (i.e. the aquiferous "canal" system) and instead possess specialised feeding apparatus and a closed "circulation" system. One specimen in the genus Asbestopluma from the Southern Ocean (Fig. 2A) (Goodwin et al., 2016) was found to be isotopically heavier than expected for given ambient DSi concentration, likely a result of different biomineralising mechanisms and internal fractionation (Hendry et al., 2015). Specialised spicules, desmas, which reinforce the skeleton, appear to be particularly linked with anomalous $\delta^{30} \mathrm{Si}$. These desmas lack a central canal, and are thought to grow via a mechanism different to filter-feeding relatives, in agreement with the hypothesis that some biochemical pathways for sponge biosilicification evolved independently between different lineages (Maldonado and Riesgo, 2007).

Other unusual forms of biosilicification have been shown to exhibit $\delta^{30} \mathrm{Si}$ values that deviate significantly from the original calibration (Fig. 1). The giant spicules of the Indian and Western Pacific hexactinellid sponge, Monorhaphis chuni (Hooper and Van Soest, 2002), are an extreme example of biosilicification, with large, basal spicules observed to grow over a metre in length (Jochum et al., 2017; Wang et al., 2009) (Fig. 2B). Laser analysis of M. chuni spicule silicon isotope composition reveals significantly heavy signatures relative to other sponges, again most likely a result of a fundamentally different silicification process. Despite this offset, there does appear to be a significant trend between $\delta^{30} \mathrm{Si}$ and DSi concentrations in M. chuni, indicating that they have potential as a complementary palaeoceanographic archive (Jochum et al., 2017). Analyses of mixed- 
sponge assemblages from seamounts within the Equatorial Atlantic revealed that heavily fused hexactinellid spicules, exhibiting a "dictyonal-type" framework (Fig. 2C), are isotopically lighter than expected. The sponge specimens in the study were graded according to degree of secondary silica fusion: the more secondary silica deposited, the greater the isotopic anomaly (Cassarino et al., 2018). These results indicate that, again, there is a different process involved in producing secondary silica "cement" that fuses primary spicules within hexactinellids.

To date, studies have identified anomalous silicon isotope fractionation behaviour in sponges relating to fundamentally different biosilicification mechanisms. However, filter-feeding, non-fused sponges also exhibit variation, as shown by the scatter in the original $\delta^{30} \mathrm{Si}$-DSi calibration (Fig. 1). Whilst localised changes in environmental parameters (notably DSi) could be responsible for some of this scatter, there has not been a full investigation of how physiological factors, such as growth rate, health and food supply, could impact silicon isotopic fractionation.

\subsection{Palaeoclimate applications}

Despite the uncertainties in understanding biomineralisation and silicon isotopic fractionation in sponges, there have already been several studies to utilise the sponge silicon isotope proxy for deep-water formation. There are a number of caveats to consider when applying sponge $\delta^{30} \mathrm{Si}$ to the geological record, including the observed variability in fractionation associated with different biosilicification mechanisms. However, this concern can - to a large part - be assuaged through avoiding potentially anomalous spicules, such as desmas (Hendry et al., 2015), or framework structures (Cassarino et al., 2018). Some palaeoceanographic studies have circumvented potential issues by picking only one form of spicule from marine sediments for archive generation (Fontorbe et al., 2016).

Other caveats in the use of the sponge $\delta^{30}$ Si proxy are more challenging to circumvent. Most critically, the residence time of silicon in the oceans is estimated as 10-15 ka (Georg et al., 2009), with the consequence that whole-ocean silicon concentration - and isotopic budgets - could shift on glacial-interglacial timescales. Changes in terrestrial weathering relating to the growth and retreat of ice sheets are likely to be one of the most important causes of regional or global seawater silicon isotope composition $\left(\delta^{30} \mathrm{DSi}\right)$ relevant to the majority of silica $\delta^{30} \mathrm{Si}$ records to date (Frings et al., 2016; Hawkings et al., 2018; Opfergelt et al., 2013). Changes in regional DSi utilisation, and so isotopic distillation, by diatoms over abrupt climatic events also need to be taken into consideration (e.g. Hendry et al., 2012). Shifts in whole-ocean silicon isotope systematics could be even more substantial (and challenging to constrain) over long-term geological timescales, in response to changes in continental silicate weathering due to mountain building or macroevolutionary changes. 
Whilst there is no available proxy for secular changes in silicon budgets, ocean modelling can be used to constrain potential changes through time (De La Rocha and Bickle, 2005).

Most palaeoclimate studies have focussed on the Late Quaternary, especially the last deglaciation and into the Holocene, during periods of time that are less likely to have witnessed large shifts in whole-ocean silicon cycling budgets. The first continuous sponge $\delta^{30} \mathrm{Si}$ records investigated impact of whole-ocean circulation shifts of the silicon cycle between glacial and interglacial states by comparing spicule composition at the Last Glacial Maximum (LGM, approximately $20 \mathrm{ka}$ ) and the modern. A shift in sedimentary sponge $\delta^{30} \mathrm{Si}$ records between the LGM and today indicate increased deep water DSi concentrations in some sectors of the Southern Ocean, especially the Pacific Sector, consistent with changes in diatom productivity and opal export (Chase et al., 2003; Ellwood et al., 2010; Hendry et al., 2010). Higher resolution spicule archives are beginning to reveal that changes in intermediate and mode water DSi concentrations are also basinspecific. In the Pacific, spicule records suggest that DSi concentrations in intermediate and mode waters were higher throughout the LGM and into the deglaciation, only declining at the beginning of the Holocene, potentially as a result of DSi-enriched deep-water upwelling (Rousseau et al., 2016). In contrast, Atlantic Ocean sedimentary spicule $\delta^{30} \mathrm{Si}$ signatures only record lighter signatures during the abrupt climate events of the deglaciation (Heinrich Event 1 and the Younger Dryas), indicative of enhanced bottom-water DSi concentrations in the mid-depth Atlantic as a result of the millennialscale reorganisation of ocean circulation (Hendry et al., 2016; Hendry et al., 2014; Hendry et al., 2012).

These new Late Quaternary sponge archives have added substantially to the debate over the extent of DSi supply, or "leakage" from the Southern Ocean to the low latitudes on glacialinterglacial timescales, and the subsequent impact on atmospheric $\mathrm{pCO}_{2}$. The "silica hypothesis" posited that diatom productivity was promoted by an increase in DSi supplied from dust dissolution during colder glacials (Harrison, 2000). A similar theory, the Silicic Acid Leakage Hypothesis (SALH), was proposed, suggesting that the addition of iron via enhanced dust deposition in the Southern Ocean impacted diatom physiology and macronutrient uptake ratios, resulting in a lower Si:N utilisation ratio and a relative increase in mode or intermediate water DSi (Brzezinski et al., 2002). Low-latitude waters would then receive a relatively high Si:N supply, promoting diatoms relative to other phytoplankton, contributing to $\mathrm{pCO}_{2}$ drawdown via alkalinity changes (Matsumoto and Sarmiento, 2008). However, the new sponge archives, in combination with other novel proxy data, suggest an alternative theory, termed the Silicic Acid Ventilation Hypothesis (SAVH), which proposes that changes in ventilation of deep waters in the Southern Ocean during these periods enhanced the 
relative DSi concentration of waters leaking into the lower latitudes, rather than surface productivity (Hendry and Brzezinski, 2014).

Spicule records have also been combined with other geochemical archives, including $\delta^{30} \mathrm{Si}$ records from diatoms and other silicifiers, to capture the whole silicon cycle (Abelmann et al., 2015; Hendry et al., 2014; Horn et al., 2011). For example, Horn et al. (2011) combined diatom $\delta^{30}$ Si and nitrogen isotope $\left(\delta^{15} \mathrm{~N}\right)$ archives with sponge $\delta^{30}$ Si records from the Southern Ocean (Hendry et al., 2010) to show that DSi utilisation was high during the deglacial at the same time as deep-water DSi concentrations and supply rates were enhanced, suggesting a strong biological pump and $\mathrm{CO}_{2}$ drawdown. Spicule archives can also be combined with diatom and sponge germanium-to-silicon ratios $(\mathrm{Ge} / \mathrm{Si}$ ) to take whole-ocean changes in silicon inventories into consideration (Ellwood et al., 2010). This approach is based on the observation that diatoms record $\mathrm{Ge} / \mathrm{Si}$ of surface seawater, whereas sponge $\mathrm{Ge} / \mathrm{Si}$ is highly fractionated and related to their ambient DSi concentrations (Ellwood et al., 2006). Any common change between Ge/Si in the two siliceous groups can be used to isolate whole-ocean changes in seawater $\mathrm{Ge} / \mathrm{Si}$. Whilst a change in this ratio could signify a change in either element, or both, modelling can be used to extract any signal of whole-ocean changes in silicon budgets from sponge $\delta^{30}$ Si archives (Ellwood et al., 2010).

The giant spicules of $M$. chuni have also been used to construct palaeoceanographic records, using laser ablation to derive $\delta^{30}$ Si profiles across latitudinal sections of individual spicules, which are thought to be able to live up to $18 \mathrm{ka}$ (Jochum et al., 2017). The offset from the original calibration profile (Fig. 1) can be taken into consideration using a novel species-specific calibration (Jochum et al., 2017). However, whilst $M$. chuni represents a novel and independent proxy, there are still challenges in deriving independent age models with which to link the observed geochemical signals with climatic events.

Over longer, geological timescales, the influences of whole-ocean changes become more significant, and robust interpretation of sponge $\delta^{30} \mathrm{Si}$ archives requires modelling to assess potential influences of seawater DSi isotopic shifts. Cenozoic sponge $\delta^{30}$ Si records have been constructed, and combined with isotopic evidence from other silicifiers to track changes in silicon cycling as far back as the Palaeogene (Egan et al., 2013; Fontorbe et al., 2016; Fontorbe et al., 2017). These records highlight that a "modern-like" marine silicon cycle was established early in the Cenozoic, with a proto-Southern Ocean silicon cycle characterised by upwelling of DSi-rich deep-waters and strong utilisation by diatoms (Egan et al., 2013), and an Atlantic-Pacific gradient in DSi concentrations (Fontorbe et al., 2017), from Eocene-Oligocene boundary. Isotopically heavy spicules and radiolarians from Atlantic sediments indicate low DSi concentrations in low-latitude waters well 
before the Eocene diversification of diatoms (Fontorbe et al., 2016). This early drawdown of DSi has been used, in combination with molecular studies (Marron et al., 2016), as evidence that other pelagic silicifiers and early diatoms may have had more impact on the marine silicon cycle than previously thought (Conley et al., 2017).

\section{Sponge grounds in the North Atlantic: silicon isotopes at the population level}

\subsection{Sponge grounds of the North Atlantic}

Sponge grounds, comprising dense aggregations or assemblages of sponges, are found throughout the North Atlantic. These environments are important for biogeochemical cycling, biodiversity, and natural products (Cathalot et al., 2015; Hogg et al., 2010; Kenchington et al., 2013; Maldonado et al., 2017), and are highly vulnerable to anthropogenic damage and oceanic change (Beazley et al., 2018; Howell et al., 2016). Given that these sponge grounds are well-characterised, they are also ideal testing grounds for population-level isotopic variation.

We have selected three different locations to test population level $\delta^{30}$ Si variation (Fig. 3, Table 1):

i) Porcupine Seabight: Pheronema carpenteri (Order Amphidiscosida, Family Pheronematidae) monospecific ground from the Northeast Atlantic (Howell et al., 2016; Rice et al., 1990);

ii) Nova Scotia: Vazella pourtalesi or 'Russian Hat' sponge (Order Lyssacinosida, Family Rosselidae) monospecific ground, from Emerald Basin (2016) and Sambro Bank Closure (2017) of the Northwest Atlantic shelf (Beazley et al., 2018);

iii) Labrador Sea: Geodia spp. (Order Tetractinellida, Family Geodiidae) multi-specific assemblages from the Boreal-Arctic astrophorid grounds/"boreal ostur" of Orphan Knoll and shelf-environments of Southwest Greenland within the Labrador Sea (Beazley et al., 2013; Howell et al., 2016; Knudby et al., 2013; Murillo et al., 2012).

3.2. Conductivity, temperature, depth (CTD) profiles and water sampling

\subsubsection{Porcupine Seabight}

Water data for the Porcupine Seabight were obtained from the electronic World Ocean Circulation Experiment database eWOCE (http://www.ewoce.org/).

\subsubsection{Nova Scotia}


During the expedition to the Emerald Basin in 2016, a continuous, full-depth profile of temperature, salinity, oxygen, and fluorescence, to within $10 \mathrm{~m}$ of bottom was made using an SBE 19plus CTD close to the site of sponge collection. A 10-L sampling bottle was closed to collect water for biological and chemical analyses $10 \mathrm{~m}$ off the seabed (Fig. A1). During the Sambro Bank expedition in 2017 , a continuous, full-depth profile of temperature and salinity was made using an SBE 25 CTD close to the site of sponge collection (Fig. A2). Nutrient data were obtained from archived data collected as part of the Atlantic Zone Monitoring Program (AZMP).

\subsubsection{Labrador Sea and coastal Greenland}

Samples were collected from Orphan Knoll and Southwest Greenland during RRS Discovery cruise DY081 in July/August 2017. All CTD casts (Fig. A3, A4) were undertaken during DY081 using a SBE 9plus underwater unit with an array of sensors, with 10L Niskin water samplers used to collect water for geochemical analysis (Hendry, 2017).

\subsection{Sponge collection}

Pheronema carpenteri (Hexactinellida) were sampled using the Irish national remotely operated vehicle (ROV), Holland I, from Porcupine Seabight (North East Atlantic) aboard the R/V Celtic Explorer, EUROFLEETS2 cruise CE15011 (Howell et al., 2015). The manipulator arm on the ROV was used to either grab sponges at the base via the anchor spicules, or to scoop sponges up using a metal mesh scoop. Sponges were then placed into bio-boxes mounted on the ROV.

Vazella pourtalesi (Hexactinellida) were collected using either a box corer or by ROV, ROPOS, from the Emerald Basin (North West Atlantic) aboard the R/V Hudson (cruise HUD16019) in July and August 2016 (Kenchington et al., 2016), and using ROPOS from the Sambro Bank on the CCGS Martha L. Black (cruise MLB2017001) in July 2017 (Beazley et al., 2017). Hexactinellid morphometrics were recorded when possible (body width and height).

Geodia sp. (Demosponge) were collected from Orphan Knoll (Labrador Sea) by the ROV, Isis, aboard the RRS Discovery in July 2017 (cruise DY081; Hendry et al., 2017). Sponges were collected either using the manipulator arms, or using a suction system.

In each case, upon recovery of the ROV to the surface, sponge samples were transferred to buckets and taken into a wet lab for processing. In the wet lab each sponge sample was labelled, measured and photographed. A sub-sample of each sponge was air-dried, before being placed in individual plastic bags or boxes for transportation.

\subsection{Sample preparation and analysis}




\subsubsection{Sponge analyses}

Small subsamples were cleaned chemically for organic matter by soaking at room temperature for 24 hours in $30 \%$ hydrogen peroxide (reagent grade $\mathrm{H}_{2} \mathrm{O}_{2}$ ) and then heating for three hours at $80^{\circ} \mathrm{C}$ in fresh $30 \% \mathrm{H}_{2} \mathrm{O}_{2}$. The samples were then rinsed in $18 \mathrm{M} \Omega . \mathrm{cm}$ Milli-Q, heated for three more hours at $80^{\circ} \mathrm{C}$ in fresh $30 \% \mathrm{H}_{2} \mathrm{O}_{2}$, and rinsed again. Lastly, the samples were rinsed in concentrated nitric acid (in-house distilled $\mathrm{HNO}_{3}$ ) a total of two times, rinsed between each stage with Milli-Q water. Approximately $1 \mathrm{mg}$ of cleaned spicules (Fig. 4) were then physically separated by hand from any lithogenic particles, weighed into clean Teflon, and dried down in concentrated $\mathrm{HNO}_{3}$ (in-house distilled) at $120^{\circ} \mathrm{C}$. The spicules were then dissolved over three days in $0.4 \mathrm{M}$ sodium hydroxide (Analar) at $100^{\circ} \mathrm{C}$, before being acidified with $8 \mathrm{~N} \mathrm{HNO}_{3}$ (in-house distilled), diluted with Milli-Q and purified using cation exchange resin (Bio-Rad AG50W X12, 200-400 mesh in $\mathrm{H}^{+}$form) following published protocols (Georg et al., 2006; Hendry and Robinson, 2012).

The purified solutions were spiked with a magnesium solution and analysed for ${ }^{28} \mathrm{Si}$, ${ }^{29} \mathrm{Si}$, and ${ }^{30} \mathrm{Si}$ using a Multi-Collector Inductively Coupled Plasma Mass Spectrometer in medium resolution mode. Sample signals were blank-corrected offline, and mass-bias corrected using magnesium isotope ratios $\left({ }^{24} \mathrm{Mg},{ }^{25} \mathrm{Mg}\right.$, and ${ }^{26} \mathrm{Mg}$ ) before being normalised to NBS28 (RM8546) following published methods to calculate both $\delta^{29} \mathrm{Si}$ and $\delta^{30} \mathrm{Si}$ values (Hendry et al., 2015). A three-isotope plot shows that $\delta^{29} \mathrm{Si}$ and $\delta^{30} \mathrm{Si}$ values for samples and standards fall on a mass-dependent linear curve, with a gradient of 0.51 (Fig. A5). Long-term reproducibility was assessed by repeat measurements of reference standards Diatomite and LMG08, yielding $\delta^{30} \mathrm{Si}$ of $+1.24 \pm 0.03 \%$ ond $-3.47 \pm 0.05 \%$ o respectively (2SE, $n=14$ and 19 respectively), which fall within error of published values (Hendry et al., 2011; Reynolds et al., 2007). Internal errors, fully propagated from blocks of 20 measurements including blank and mass-bias corrections, were typically $0.05 \%$ for $\delta^{29} \mathrm{Si}$ and $0.10 \%$ or ${ }^{30} \mathrm{Si}$. Repeat measurements of $\delta^{29} \mathrm{Si}$ and $\delta^{30} \mathrm{Si}$ (e.g. Vazella 5-022 from MLB2017001) agreed within \pm 0.04 and $\pm 0.03 \%$ respectively.

\subsubsection{Seawater DSi analyses}

Samples for inorganic nutrients were all analysed by comparable methods either at the Bedford Institute of Oceanography (BIO) or in the Plymouth Marine Laboratory (PML) using the latest GO-SHIP protocols (Hydes et al., 2010). The analysis was carried out using a SEAL analytical AAlll segmented flow colorimetric auto-analyser using classical analytical techniques for nitrate, nitrite, DSi and phosphate, as described in Woodward and Rees (2001). Seawater nutrient reference materials (KANSO Ltd. Japan), or cross-checked in-house standards, were analysed to check analyser performance and to guarantee the quality control of the final reported data. The typical 
uncertainties of the analytical results were between $2-3 \%$, and the limits of detection were $0.02 \mu \mathrm{M}$ for nitrate and phosphate, $0.01 \mu \mathrm{M}$ for nitrite, and DSi did not ever approach the limits of detection.

Water DSi silicon isotope ( $\left.\delta^{30} \mathrm{DSi}\right)$ analysis methods are fully described in Cassarino et al., 2018. Briefly, silicon was pre-concentrated twice by the additional of sodium hydroxide $(1.2 \% \mathrm{v} / \mathrm{v} 1 \mathrm{M}$ $\mathrm{NaOH}$, followed by $1 \% \mathrm{v} / \mathrm{v} 1 \mathrm{M} \mathrm{NaOH} 24$ hours later) to precipitate magnesium hydroxide. The precipitate is rinsed with dilute sodium hydroxide $(0.001 \mathrm{M} \mathrm{NaOH})$ before redissolution in $8 \mathrm{M}$ distilled $\mathrm{HNO}_{3}$, dilution in $18 \mathrm{M} \Omega . \mathrm{cm}$ Milli-Q water, and chemical purification using cation exchange resin as outlined above. Mass spectrometric analysis was carried out as for the sponge samples, with the addition of $0.05 \mathrm{M} \mathrm{HCl}$ and $0.003 \mathrm{M} \mathrm{H}_{2} \mathrm{SO}_{4}$ to standards and samples prior to analysis to account for any potential matrix effects (Hughes et al., 2011). The ALOHA " 300 " and "1000" seawater standards were measured alongside the seawater samples to assess analytical accuracy and precision, and yielded values within error of published data $\left(\delta^{30} \mathrm{Si}=+1.10 \pm 0.15 \%\right.$ and $+1.43 \pm 0.19$ \%o (2SD internal precision), respectively) (Cassarino et al., 2018; Grasse et al., 2017).

\subsubsection{Sponge identification}

Sponges from the genus Geodia collected during DY081 were identified to species level after collection. To isolate the spicules, sponge tissue was digested in bleach (15\% Sodium Hypochlorite). Spicules were then washed twice with water and once in 95\% ethanol, allowing the spicules to settle out of the washing solution for $\sim 45$ minutes between each change. A few drops of the final ethanol solution were placed on a slide and then this was placed on a heat plate, evaporating the alcohol and leaving the spicules behind. The spicules were mounted in Canada balsam covered with a glass coverslip. A thick tissue section $(\approx 0.2 \mathrm{~mm})$ was cut using a scalpel and also mounted using Canada balsam. Spicule measurements were made using an Olympus BX43 microscope, with thirty spicules measured per spicule type. Digital photos were taken using the combination of the Olympus BX43 microscope with a SC50 camera and are available upon request.

\subsection{Sponge ground results: insight into population variance}

The new $\delta^{30} \mathrm{Si}$ sponge and seawater $\delta^{30} \mathrm{DSi}$ data are shown in Table A1. The $\delta^{30} \mathrm{Si}$ values for the hexactinellid specimens range from -1.24 to $-2.49 \%$; the Geodia specimens ranged from -1.08 to $-2.37 \%$.

\subsubsection{Monospecific aggregations}

The $P$. carpenteri aggregation specimens show a mean $\delta^{30} \mathrm{Si}$ value of $-2.07 \%$ and a variance $0.04 \%$ o ( $n=29$; Fig. 5). There is no significant correlation between $\delta^{30} \mathrm{Si}$ and calculated body volume 
(correlation coefficient $=0.238 ; p>0.05 ;$ Fig. A6), assuming an ellipsoid form. There is also no significant correlation between temperature or salinity and spicule $\delta^{30} \mathrm{Si}(\mathrm{p}>0.05)$.

Compared to the $P$. carpenteri samples, the specimens from the $V$. pourtalesi aggregations show higher mean $\delta^{30} \mathrm{Si}$ values of $-1.59 \%$ (variance of $0.03 \%$ ) and $-1.65 \%$ (variance of $0.02 \%$ ) for the Emerald Basin and Sambro Basin specimens respectively. There is no significant difference between either the means (note the low power of this statistical test) or the medians of the two aggregations of $V$. pourtalesi (one-tailed t-test, $p=0.198$, power $=0.210$; rank sum test, $p=0.603$ ). The overall variance of the $V$. pourtalesi specimens was $0.02 \%$ o $(n=24)$. There is a significant correlation with body volume (correlation coefficient $=0.758 ; p<0.01, n=12$; Fig. A6), assuming a cylindrical body form. Note not all of the specimens have morphometric data available, so the statistical analysis in this case was carried out on a small subset of specimens, and the correlation is largely driven by one outlier (Fig. A6). Both hexactinellid populations passed a Shapriro-Wilk normality test (Table 2; Fig. $5 B)$.

Silicon isotope fractionation was calculated using Equation 2 (Table A1), using the measured isotopic composition of the sponge spicules and seawater samples (Fig. 7A). The closest located seawater sample was used for each specimen (or mean values if specimen was located between two Niskin sampling events). Seawater samples were not available for the $P$. carpenteri samples, so a $\delta^{30} \mathrm{DSi}$ value of $+1.5 \%$ was chosen for the ambient composition based on published water column profiles from the Atlantic Ocean (de Souza et al., 2012). The mean $\Delta^{30} \mathrm{Si}$ values for the $V$. pourtalesi and $P$. carpenteri groups were calculated to be $-3.21 \%$ and $-3.57 \%$ respectively. The two groups show equal variance in their population fractionation factors (Brown-Forsythe test passed, $p=0.438$; both groups have a variance of $\sim 0.04 \%$ ) but have significantly different means (two-tailed t-test, $p<$ 0.001 , power 0.998 for $\alpha=0.05$ ) with the greater mean fractionation factor observed for the $P$. carpenteri population (one-tailed t-test, $\mathrm{p}<0.001$, power 0.999 for $\alpha=0.05$ ).

\subsubsection{Multi-specific assemblages}

The mean $\delta^{30} \mathrm{Si}$ composition for all the Geodia specimens was $-1.64 \%$, with a variance of $0.09 \%$ ( $n=20)$. All Geodia specimens, taken as one population, passed a Shapriro-Wilk normality test (Table 2). Although variability between individual is greater for the astrophorids compared to the hexactinellid monospecific aggregations, this group represents a number of different species within the same genus. Dividing the group into species (Fig. 6) shows that some of the variability could be a result of genetic differences. For most of the astrophorids, the variance is more aligned with the hexactinellid populations when separated into species: G. atlantica, G. hentscheli, $G$. 
close phylogenetic relationships (Cardenas et al., 2013). However, G. hentscheli, G. parva and G. phlegraei are more variable (G. parva and G. phlegraei groupings both have lighter isotopic specimens, and are closely allied on the molecular phylogeny of the genus). G. barretti is significantly heavier than the majority of the other specimens, although the specimen was the only one located in the northern-most collection site off west Greenland.

Initial tests indicated that different spicules from an astrophorid from the Southern Ocean have the same $\delta^{30} \mathrm{Si}$ composition within uncertainty $\left(\delta^{30} \mathrm{Si}\right.$ of $-2.87 \pm 0.21 \%$ ond $-2.96 \pm 0.23 \%$ ofor subsamples of a sterraster-dominated dermal layer and a parenchymal layer respectively) (Hendry et al., 2010). The results here also support a relatively uniform isotopic composition between individuals, at least for most Geodia species.

Again, the fractionation of silicon isotopes was calculated using Equation 2 (Table A1), using the measured sponge and seawater $\delta^{30} \mathrm{DSi}$ values (Fig. 6). The different Geodia species show some variation in $\Delta^{30} \mathrm{Si}$, with mean of $-2.94 \%$ with a variance of $0.08 \%$. However, taking the environmental differences in ambient $\delta^{30} \mathrm{DSi}$ between sampling locations, through the calculation of fractionation factors, can only eliminate some of the variation between species. For example, the $G$. barretti specimen from the northern sampling site was collected from somewhat isotopically heavier waters than the other specimens (Table A1). The remaining variability must be due to other environmental differences, in addition to physiological differences between the specimens.

\section{Discussion}

4.1. New calibration between sponge silicon isotopes and ambient dissolved silicon concentrations

A compilation of all published data reveals the extreme variation in the fractionation of stable silicon isotopes during spicule growth (Fig. 7A and B). There are some significant outliers from the original calibration curve (Fig. 1), which comprise sponges with atypical biosilicification processes including heavily fused hexactinellids (Cassarino et al., 2018); carnivorous sponges (Hendry et al.,

471 2015), and the giant spicules of $M$. chuni (Jochum, 2017). If the atypical silicifiers are removed from 472 the calibration (Fig. 7B), the remaining sponge specimens (largely comprising filter-feeding sponges 473 that produce loose spicules) still show a significant correlation between isotopic fractionation and 474 DSi (Equ. 6):

$$
\Delta^{30} S i=-4.6(0.1)+\frac{27.6(1.9)}{(7.4(1.9) \times D S i)}
$$

$476 \quad$ (Adjusted $\mathrm{R}^{2}=0.46, \mathrm{p}<0.001$ ). 
Our new data from the North Atlantic sponge grounds are consistent with the original non-

480

481

482

483

484

485

486

487

488

489

490

491

492

493

494

495

496

497

498

499

500

501

502

503

504

505

506

507

508

509

510

linear DSi- $\delta^{30}$ Si relationship found previously, especially in comparison to sponges with atypical silicification mechanisms that form clear outliers. However, there is still scatter in the empirical relationship, which can be explored with the results from the monospecific assemblages, and can be used to largely exclude genetic differences as a driving factor in isotopic fractionation. Northwest Atlantic $P$. carpenteri aggregation is isotopically light for the given ambient DSi concentrations and so plots below the main calibration line (Fig. 7A). Given that both the Pheronema and Vazella genera belong to orders (Amphidiscosida and Lyssacinosida respectively) that are not characterised by fused, dictyonal spicules (Tabachnick et al., 2017), and the specimens analysed here comprised either loose spicules or spicules fused lightly at nodes (Fig. 4), secondary hypersilicification is not a possible mechanism for driving silica isotopic compositions towards lighter values (Cassarino et al., 2018).

One possible reason behind this variation within a monospecific aggregation is that there are variations in the growth rate (linked with food supply, or health) between the individuals and, so, differences in the specific values of the uptake kinetics parameters and a variation in isotopic fractionation (Equation 4). However, a lack of relationship between body size and $\delta^{30} \mathrm{Si}$ in the $P$. carpenteri samples, and only a statistically weak relationship between the parameters in the $V$. pourtalesi specimens, argues against a growth rate effect in this case (Fig. A6).

An alternative explanation as to why these sponge ground specimens have more negative $\delta^{30} \mathrm{Si}$ values than expected - or predicted by the biological model shown in Equation 4 - is that the sponges obtain DSi for biomineralising partially from recycled sponge silica, which is available as a result of the close proximity of the densely aggregated individuals. We have constructed a simple model to test this hypothesis, varying the percentage of DSi taken up by the sponge originating from recycled spicules rather than bottom waters, and using isotopic mass balance to calculate the subsequent impact on spicule $\delta^{30} \mathrm{Si}$ values (Table A2). Our model implies that the $P$. carpenteri sponges could be biomineralising from a solution comprising 40-60\% recycled silica, with a lower degree of recycling $(<40 \%)$ occurring in the $V$. pourtalesi aggregations (Fig. 8). A high degree of recycling in $P$. carpenteri sponge grounds is consistent with the observation of thick spicule mats, with aggregations of living and dead sponges commonly found together (Barthel et al., 1996; Bett and Rice, 1992). Variations in the extent of spicule recycling could be responsible for the isotopic fractionation scatter observed in population level in dense sponge grounds. 

found in mixed assemblages still shows a degree of scatter, even when atypical silicification processes are accounted for and removed from the calibration. Despite growing under almost identical environmental conditions, mixed assemblages of sponges from a particular area exhibit a wide range in $\delta^{30} \mathrm{Si}$, a larger range than for monospecific aggregations (e.g. Cassarino et al., 2018). Part of this variability could be a result of silica recycling (Fig. 8), although this mechanism can only drive the system towards lighter isotopic compositions.

Instead, the variation could be a result of a combination of genetic variation and physiology. Our new Geodia results show that, generally, a good proportion of the scatter in isotopic composition can be accounted for by species-specific variations in fractionation (Fig. 6). The half saturation constant and maximum incorporation rate for polymerisation varies between species, and potentially even within species as a result of differences in food availability or health (López-Acosta et al., 2018; López-Acosta et al., 2016). We have explored the impact on silicon isotopic fractionation of such differences in uptake parameters using the simple biological model in Equation 4 (Cassarino et al., 2018), and found that a large degree of variability can be explained by differences in kinetics between species (Fig. 9A and B).

The majority of the analyses of sponge $\delta^{30} \mathrm{Si}$ variation to date have been carried out in deep water sponges, where environmental variability is relatively low. Shallow water sponges, especially those in the littoral or sublittoral zone, are likely to be subject to extreme environmental changes on a range of timescales (diurnal, seasonal, annual), and so could be expected to show a larger degree of isotopic variability driven by ambient conditions. Any differences in silicon isotope fractionation between species may also expected to be amplified, depending on factors such as growing season and growth rate. Quantifying the variability in sponge $\Delta^{30} \mathrm{Si}$ in these ecosystems may be particularly challenging, given the requirement to characterise changes in sponge growth and ambient conditions (e.g. seawater $\delta^{30} \mathrm{Si}$ variations) over a range of spatial scales.

\subsubsection{Differences between higher taxonomic rankings}

There are fundamental differences in biosilicification between hexactinellids and demosponges, which might be expected to manifest in contrasting isotopic fractionation (Cassarino et al., 2018). Demosponges fuse the concentric silica layers that form around the axial canal, whereas they remain distinct layers in hexactinellids (Aizenberg et al., 2005; Müller et al., 2009; Wang et al., 2011). Furthermore, the organic composition of the silicification proteins in the two groups differ: hexactinellids have higher molecular weight proteins than those isolated from 
demosponges (Weaver et al., 2003). The interaction between the polymerising silica and these different organic molecules could result in divergent isotopic fractionation (Cassarino et al., 2018).

Despite these clear differences in silicification mechanism, there is no clear answer at this stage as to what extent are there differences in isotopic behaviour between hexactinellids and demosponges. A qualitative analysis of the whole dataset (excluding 'lithistids', Asbestopluma sp. and $M$. chuni) suggests that the DSi- $\delta^{30}$ Si relationships are different between hexactinellids and demosponges (Fig. 7B). However, this whole dataset also illustrates that the two groups are separated in DSi "space", with demosponges able to grow under lower DSi concentrations than hexactinellids, such that the difference in isotopic fractionation could be a consequence of distinct habitat preferences. To account for any DSi influence, one approach is to normalise the $\delta^{30} \mathrm{Si}$ data, by calculating a residual for each datapoint relative to the best-fit hyperbolic regression. This method has previously revealed a lack of systematic differences between demosponges and hexactinellids (Cassarino et al., 2018). Alternatively, it is possible to statistically assess the differences in fractionation between the two groups, but only within the DSi range under which both groups are present (10 to $100 \mu \mathrm{M}$ DSi). Under these constraints, there is no significant difference between the mean $\delta^{30} \mathrm{Si}$, or DSi- $\delta^{30} \mathrm{Si}$ intercepts, of hexactinellids and demosponges once DSi differences are taken into account (ANCOVA, $F=0.045, p=0.833$; Fig. A7). This suggests that, despite some fundamental differences in silicification behaviour between hexactinellids and demosponges, there is no significant impact on stable silicon isotopic fractionation, at least for filter-feeding sponges without dictyonal framework skeletons. This suggests that using a mixture of hexactinellid and demosponge spicules, which are often challenging to distinguish within sediments, to measure $\delta^{30} \mathrm{Si}$ variations in marine cores should produce robust and interpretable archives of past oceanic change provided spicules with clearly different morphology (e.g. giant spicules, desmas, heavily fused spicules) are avoided.

\section{Conclusion and outlook}

Diatom productivity, and oceanic export production, relies on the upwelling of deep-waters for a supply of dissolved silicon. If we are to quantify future changes in marine carbon cycling, we need to be able to predict future changes in diatom growth and, so, changes in the supply of DSi and other nutrients to the surface through physical and chemical processes. One of the best analogues we have for how the oceans may respond in the future is the geological record: understanding how diatoms have responded to past climate events can inform greatly on potential upcoming change. However, because of the reliance of diatoms on deep-waters, we need an archive of bottom water DSi concentrations if we are to tease apart the relative impacts of changes in physical upwelling as 
opposed to water mass variability and remineralisation. To date, sponge spicules are the only available archive of deep-water silica, especially spicule $\delta^{30}$ Si values, which have been shown by a number of studies to have a statistically significant relationship with ambient DSi. There are important caveats, as common to all novel geochemical proxies, which must be taken into consideration for robust interpretation of downcore archives. Atypical biomineralisation processes (hypersilicification, the growth of giant basal spicules, and silica production in carnivorous sponges) have an impact on silicon isotopic compositions. However, these spicule types can largely be disregarded for palaeoceanographic studies as they are morphologically distinct.

There are further, more complex challenges surrounding unknown variations in ambient DSi and seawater $\delta^{30} \mathrm{Si}$, either on the small scale in the immediate surroundings of the growing sponge (e.g. silica recycling within dense sponge aggregations or within individuals as shown in this study) or secular changes on large spatial scales and over long periods of time that exceed the residence time of silicon in seawater. However, multi-proxy approaches and modelling efforts will help to understand these challenging caveats. Robust dating methods and age models are also required, which have in spicule $\delta^{30} \mathrm{Si}$ studies - to date - relied entirely on the dating of surrounding material (e.g. by radiocarbon dating or foraminiferal isotope stratigraphy) and do not take into consideration the potential age-differential between sedimentary components. Improvements in radiocarbon dating of sponge organic matter may provide a better handle on how long sponges live, and the absolute ages of spicules within sediments (Fallon et al., 2010). Lastly, and perhaps most fundamentally, we do not have a full understanding of the biochemical pathways that lead to $\delta^{30} \mathrm{Si}$ variations between sponges. Our new results show that there is scatter in the spicule DSi- $\delta^{30} \mathrm{Si}$ relationship, even between specimens from monospecific aggregations that have grown under the same environmental conditions, indicating that there is more to understand about how the health of individuals can impact biological fractionation of silicon isotopes. A greater understanding of biomineralisation pathways, and how they differ between sponge groups, will aid our mechanistic understanding of how sponges fractionate silicon isotopes.

\section{Acknowledgements}

This research was funded by European Research Council project ICY-LAB (ERC-2015-STG grant agreement number 678371), and EU Horizon 2020 project SponGES (H2020-BG-2015-2 grant agreement number 679849). K. L. Howell is funded by the EU Seventh Framework Programme EUROFLEETS2 (FP7/2007-2013 grant agreement number 312762). Thanks to Christopher D. Coath for assistance with mass spectrometry, and Paco Cárdenas for advice on Geodia identification. Many thanks to Ellen Kenchington and Lindsay Beazley for collection of Vazella pourtalesi sponges and co- 
609 located seawater samples, and for supplying details of their previous benthic surveys on Orphan

610 Knoll which assisted with cruise planning. Canadian funding was received from the International

611 Governance Strategy (IGS) fund of the Department of Fisheries and Oceans Canada Project "Marine

612 Biological Diversity Beyond Areas of National Jurisdiction (BBNJ): 3-Tiers of Diversity (Genes-Species-

613 Communities)" to E. K. We also thank Joana Xavier, Manuel Maldonado and Hans Tore Rapp for

614 support through the SponGES project. Many thanks to two anonymous reviewers for their

615 constructive comments.

616 Data availability: An electronic copy of the new data from this study is available at

617 https://doi.pangaea.de/10.xxxx/PANGAEA.xxxxxx 


\begin{tabular}{|c|c|c|c|c|c|c|c|c|}
\hline Location & Species & $\mathrm{n}$ & $\begin{array}{l}\text { Depth } \\
\text { (m) }\end{array}$ & $\begin{array}{l}\text { Temperature } \\
\left({ }^{\circ} \mathrm{C}\right)\end{array}$ & Salinity & $\begin{array}{l}\text { Oxygen } \\
(\mu \mathrm{mol} / \mathrm{L} \\
)\end{array}$ & $\mathrm{DSi}(\mu \mathrm{M})$ & $\begin{array}{l}\mathrm{NO}_{3} \\
(\mu \mathrm{M})\end{array}$ \\
\hline $\begin{array}{l}\text { Porcupine } \\
\text { Seabight }\end{array}$ & $\begin{array}{l}\text { Pheronema } \\
\text { carpenteri }\end{array}$ & 29 & $\begin{array}{l}1204- \\
1407\end{array}$ & $6.5-7.1$ & $\begin{array}{l}35.2- \\
35.4\end{array}$ & $\begin{array}{l}245- \\
255^{a}\end{array}$ & $\begin{array}{l}11.3- \\
11.6^{\mathrm{a}}\end{array}$ & $\begin{array}{l}18.1- \\
18.4^{a}\end{array}$ \\
\hline $\begin{array}{l}\text { Emerald } \\
\text { Basin }\end{array}$ & $\begin{array}{l}\text { Vazella } \\
\text { pourtalesi }\end{array}$ & 8 & $\begin{array}{l}184- \\
206\end{array}$ & $11.0-11.1$ & 35.2 & $\begin{array}{l}121- \\
126\end{array}$ & $\begin{array}{l}16.9 \pm \\
0.5\end{array}$ & $\begin{array}{l}18.9 \\
\pm 0.2\end{array}$ \\
\hline $\begin{array}{l}\text { Sambro } \\
\text { Basin }\end{array}$ & $\begin{array}{l}\text { Vazella } \\
\text { pourtalesi }\end{array}$ & 16 & $\begin{array}{l}154- \\
161\end{array}$ & $\sim 10$ & $\sim 34.7$ & $\begin{array}{l}200- \\
220^{a}\end{array}$ & $\begin{array}{l}12.0 \pm \\
0.4\end{array}$ & $\begin{array}{l}17.5 \pm \\
2.6\end{array}$ \\
\hline $\begin{array}{l}\text { Orphan } \\
\text { Knoll }\end{array}$ & Geodia & 13 & $\begin{array}{l}1763- \\
3463\end{array}$ & $2.1-3.4$ & 34.9 & $\begin{array}{l}265- \\
272\end{array}$ & $6-15$ & \\
\hline $\begin{array}{l}\text { Coastal } \\
\text { Greenland }\end{array}$ & Geodia & 2 & $\begin{array}{l}846- \\
1146\end{array}$ & $3.9-4.5$ & 34.9 & $\begin{array}{l}280- \\
290\end{array}$ & $9-10$ & \\
\hline
\end{tabular}


620

\section{Species $\mathbf{n}$ W-Statistic P value Passed?}

621

\begin{tabular}{|c|c|c|c|c|}
\hline Pheronema carpenteri & 29 & 0.975 & 0.706 & yes \\
\hline Vazella pourtalesi & 25 & 0.975 & 0.796 & yes \\
\hline Emerald Bank & 17 & 0.851 & 0.097 & yes \\
\hline Sambro Bank & 8 & 0.956 & 0.592 & yes \\
\hline Geodia sp. & 20 & 0.932 & 0.170 & yes \\
\hline
\end{tabular}


Figure 1: Original calibration studies figure (Hendry et al., 2010, Wille et al., 2010; Hendry \& Robinson, 2012) of apparent sponge silicon isotope fractionation (denoted by $\Delta^{30} \mathrm{Si}$, Equation 2 ) and ambient dissolved silicon concentrations (DSi). Symbols highlight the different collection expeditions. Error bars show ranges for DSi in $\mu \mathrm{M}$, and 2SD for isotopic fractionation.

Figure 2: Scanning Electron Microscope images of sponge spicules. A) basal spicules from Asbestopluma sp. (Hendry et al., 2015) where des = desmas and ani = anisostrongyes; B) crosssection through spicule of Monorhaphis chuni (Jochum et al., 2017); C) fused framework of hexactinellid from the tropical Atlantic (Cassarino et al., 2018).

Figure 3: Location of collection sites of the new sponge specimens, from North Atlantic sponge grounds. Black symbols show hexactinellids, yellow symbols show demosponges. Squares show Vazella pourtalesi samples from Emerald Basin (solid) and Sambro Basin (hollow); triangles show Pheronema carpenteri samples from Porcupine Seabight; stars show Geodia (demosponge) specimens from boreal sponge grounds.

Figure 4: Scanning Electron Microscope images of Vazella, Pheronema and Geodia specimens, after chemical cleaning and before dissolution. Scale bar shows $100 \mu \mathrm{m}$. Figure 5: Silicon isotopic composition $\left(\delta^{30} \mathrm{Si}\right)$ of sponge-ground forming hexactinellids: $\mathrm{A}$ ) all datapoints and B) all Vazella and Pheronema data plotted as histograms. Scale bars show uncertainties based on repeat measurements of sponge standard LMG08 $( \pm 2 \mathrm{SD})$.

Figure 6: Silicon isotopic composition ( $\delta^{30} \mathrm{Si}$ ) of Geodia specimens (black circles). Scale bars show uncertainties based on repeat measurements of sponge standard LMG08 ( $\pm 2 \mathrm{SD})$. Grey circles show silicon isotopic fractionation ( $\Delta^{30} \mathrm{Si}$, see Equation 2). Figure 7: A) Compilation of all $\mathrm{Si}$ isotopic fractionation data $\left(\Delta^{30} \mathrm{Si}\right.$, see Equation 2) for all available sponge spicule studies. Scale bars show fully propagated errors ( $\pm 2 \mathrm{SD})$. Symbols show different sponge types, where FF = filter-feeding (non-carnivorous) sponges excluding heavily fused hexactinellids and M. chuni. (NB: "lithistids" have been removed from the Wille et al., 2010 dataset). B) spicule Si isotope data comparing hexactinellids and demosponges, excluding carnivorous, heavily fused sponges and M. chuni.

Figure 8: Sponge ground modelling results. Large circles show new data from sponge-ground forming hexactinellids; small grey circles show published data, where FF = filter-feeding (non-carnivorous) sponges excluding heavily fused hexactinellids and $M$. chuni. For model details, see main text. 
653 Figure 9: Uptake of silicon by sponges modelled using Michaelis-Menten kinetics. For model details,

654 see main text. A) DSi consumption and B) Si isotopic fractionation (Cassarino et al., 2018). Silicon

655 uptake data from (López-Acosta et al., 2018; López-Acosta et al., 2016; Maldonado et al., 2011;

656 Reincke and Barthel, 1997).

\section{Table captions}

658 Table 1: Specimen sample table, including environmental parameters. ${ }^{a}$ From GLODAP dataset.

659 Table 2: Shapriro-Wilk normality test results for specimens from the three sponge grounds.

660 
662 Abelmann, A., Gersonde, R., Knorr, G., Zhang, X., Chapligin, B., Maier, E., Esper, O., Friedrichsen, H., 663 Lohmann, G. and Meyer, H. (2015) The seasonal sea-ice zone in the glacial Southern Ocean as a 664 carbon sink. Nature communications 6.

665 Aizenberg, J., Weaver, J.C., Thanawala, M.S., Sundar, V.C., Morse, D.E. and Fratzl, P.J.S. (2005)

666 Skeleton of Euplectella sp.: structural hierarchy from the nanoscale to the macroscale. 309, 275-

\section{8.}

668 Antcliffe, J.B., Callow, R.H. and Brasier, M.D. (2014) Giving the early fossil record of sponges a 669 squeeze. Biological Reviews 89, 972-1004.

670 Baines, S.B., Twining, B.S., Brzezinski, M.A., Krause, J.W., Vogt, S., Assael, D. and McDaniel, H.J.N.G. 671 (2012) Significant silicon accumulation by marine picocyanobacteria. 5, 886.

672 Barthel, D., Tendal, O. and Thiel, H.J.M.E. (1996) A Wandering Population of the Hexactinellid 673 Sponge Pheronema carpenteri on the Continental Slope off Morocco, Northwest Africa. 17, 603674616.

675 Beazley, L.I., Kenchington, E.L., Murillo, F.J. and Sacau, M.d.M. (2013) Deep-sea sponge grounds 676 enhance diversity and abundance of epibenthic megafauna in the Northwest Atlantic. Journal of 677 Marine Science 70, 1471-1490.

678 Beazley, L.I., Pham, C., Murillo, F.J. and Kenchington, E. (2017) Cruise report for the DFO/SponGES 679 CCGS Martha L. Black Oceanographic Mission (MLB2017001), August 31 to September 7, 2017, 680 Canadian Technical Report of Fisheries and Aquatic Sciences 3242. Bedford Institute of

681 Oceanography.

682 Beazley, L.I., Wang, Z., Kenchington, E., Yashayaev, I., Rapp, H.T., Xavier, J.R., Murrillo, F.J., Fenton, D. 683 and Fuller, S. (2018) Predicted distribution of the glass sponge Vazella pourtalesi on the Scotian Shelf 684 and its persistence in the face of climatic variability. PLoS One 13(10), e0205505.

685 https://doi.org/0205510.0201371/journal.pone.0205505.

686 Bett, B. and Rice, A. (1992) The influence of hexactinellid sponge (Pheronema carpenteri) spicules on 687 the patchy distribution of macrobenthos in the porcupine seabight (bathyal ne atlantic). Ophelia 36, $688 \quad 217-226$.

689 Brzezinski, M.A., Sigman, D.M., Sarmiento, J.L., Matsumoto, K., Gruber, N., Rau, G.H. and Coale, K.H. 690 (2002) A switch from $\mathrm{Si}(\mathrm{OH})_{4}$ to $\mathrm{NO}_{3}{ }^{-}$depletion in the glacial Southern Ocean. Geophysical Research 691 Letters 29, 1564.

692 Cardenas, P., Rapp, H.T., Klitgaard, A.B., Best, M., Thollesson, M. and Tendal, O.S.J.Z.J.o.t.L.S. (2013)

693 Taxonomy, biogeography and DNA barcodes of Geodia species (Porifera, Demospongiae,

694 Tetractinellida) in the Atlantic boreo-arctic region. 169, 251-311.

695 Cassarino, L., Coath, C.D., Xavier, J.R. and Hendry, K.R. (2018) SILICON ISOTOPES OF DEEP-SEA

696 SPONGES: NEW INSIGHTS INTO BIOMINERALISATION AND SKELETAL STRUCTURE.

697 Cathalot, C., Van Oevelen, D., Cox, T.J., Kutti, T., Lavaleye, M., Duineveld, G. and Meysman, F.J.

698 (2015) Cold-water coral reefs and adjacent sponge grounds: Hotspots of benthic respiration and 699 organic carbon cycling in the deep sea. Frontiers in Marine Science 2, 37.

700 Chase, Z., Anderson, R.F., Fleisher, M.Q. and Kubik, P.W. (2003) Accumulation of biogenic and 701 lithogenic material in the Pacific sector of the Southern Ocean during the past 40,000 years. Deep702 Sea Research II 50, 799-832.

703 Conley, D.J., Frings, P.J., Fontorbe, G., Clymans, W., Stadmark, J., Hendry, K.R., Marron, A.O. and De 704 La Rocha, C.L. (2017) Biosilicification drives a decline of dissolved Si in the oceans through geologic time. Frontiers in Marine Science 4, 397.

De La Rocha, C. and Bickle, M. (2005) Sensitivity of silicon isotopes to whole-ocean changes in the silica cycle. Marine Geology 217, 267-282.

708 De La Rocha, C.L. (2003) Silicon isotope fractionation by marine sponges and the reconstruction of 709 the silicon isotope composition of ancient deep water. Geology 31, 423-426. 

Cosmochimica Acta 46, 1449-1458. primes Earth for Antarctic glaciation. Earth and Planetary Science Letters.

Ellwood, M.J., Kelly, M., Maher, W.A. and de Deckker, P. (2006) Germanium incorporation into sponge spicules: development of a proxy for reconstructing inorganic germanium and silicn concentrations in seawater. Earth and Planetary Science Letters 243, 749-759.

Ellwood, M.J., Wille, M. and Maher, W. (2010) Glacial silicic acid concentrations in the Southern Ocean. Science 330, 1088-1091.

Fallon, S., James, K., Norman, R., Kelly, M. and Ellwood, M. (2010) A simple radiocarbon dating method for determining the age and growth rate of deep-sea sponges. Nuclear Instruments and Methods in Physics Research Section B: Beam Interactions with Materials and Atoms 268, 12411243.

Fontorbe, G., Frings, P.J., Christina, L., Hendry, K.R. and Conley, D.J. (2016) A silicon depleted North Atlantic since the Palaeogene: Evidence from sponge and radiolarian silicon isotopes. Earth and Planetary Science Letters 453, 67-77.

Fontorbe, G., Frings, P.J., De La Rocha, C.L., Hendry, K.R., Carstensen, J. and Conley, D.J. (2017) Enrichment of dissolved silica in the deep Equatorial Pacific during the Eocene-Oligocene. Paleoceanography.

Frings, P.J., Clymans, W., Fontorbe, G., Christina, L. and Conley, D.J. (2016) The continental Si cycle and its impact on the ocean Si isotope budget. Chemical Geology 425, 12-36.

Georg, R.B., Reynolds, B.C., Frank, M. and Halliday, A.N. (2006) New sample preparation techniques for the determination of Si isotopic composition using MC-ICPMS. Chemical Geology 235, 95-104. Georg, R.B., West, A.J., Basu, A.R. and Halliday, A.N. (2009) Silicon fluxes and isotope composition of direct groundwater discharge into the Bay of Bengal and the effect on the global ocean silicon budget. Earth and Planetary Science Letters 283, 67-74.

Goodwin, C., Berman, J., Downey, R. and Hendry, K. (2016) Carnivorous sponges (Porifera, Demospongiae, Poecilosclerida, Cladorhizidae) from the Drake Passage (Southern Ocean) with a description of eight new species and a review of the family Cladorhizidae in the Southern Ocean. Invertebrate Systematics.

Grasse, P., Brzezinski, M.A., Cardinal, D., de Souza, G.F., Andersson, P., Closset, I., Cao, Z., Dai, M., Ehlert, C. and Estrade, N. (2017) GEOTRACES inter-calibration of the stable silicon isotope composition of dissolved silicic acid in seawater. Journal of Analytical Atomic Spectrometry 32, 562578.

Guillermic, M., Lalonde, S.V., Hendry, K.R. and Rouxel, O.J.J.G.e.C.A. (2017) The isotope composition of inorganic Germanium in seawater and deep sea sponges. 212, 99-118.

Harrison, K.G. (2000) Role of increased marine silica input on paleo-pCO2 levels. Paleoceanography 15, 292-298.

Hawkings, J.R., Hatton, J.E., Hendry, K.R., de Souza, G.F., Wadham, J.L., Ivanovic, R., Kohler, T.J., Stibal, M., Beaton, A. and Lamarche-Gagnon, G. (2018) The silicon cycle impacted by past ice sheets. Nature Communications 9, 3210.

Hendry, K.R. (2017) RRS Discovery Cruise DY081, July 6th - August 8th 2017. National Marine Facilities.

Hendry, K.R. and Andersen, M.B. (2013) The zinc isotopic composition of siliceous marine sponges: investigating nature's sediment traps. Chemical Geology. 
Hendry, K.R. and Brzezinski, M.A. (2014) Using silicon isotopes to understand the role of the Southern Ocean in modern and ancient biogeochemistry and climate Quaternary Science Reviews 89, 13-26.

Hendry, K.R., Georg, R.B., Rickaby, R.E.M., Robinson, L.F. and Halliday, A.N. (2010) Deep ocean nutrients during the Last Glacial Maximum deduced from sponge silicon isotopic compositions. Earth and Planetary Science Letters 292, 290-300.

Hendry, K.R., Gong, X., Knorr, G., Pike, J. and Hall, I.R. (2016) Deglacial diatom production in the tropical North Atlantic driven by enhanced silicic acid supply. Earth and Planetary Science Letters 438, 122-129.

Hendry, K.R., Leng, M.J., Robinson, L.F., Sloane, H.J., Blusztjan, J., Rickaby, R.E.M., Georg, R.B. and Halliday, A.N. (2011) Silicon isotopes in Antarctic sponges: an interlaboratory comparison. Antarctic Science 23, 34-42.

Hendry, K.R., Marron, A.O., Vincent, F., Conley, D.J., Gehlen, M., Ibarbalz, F.M., Quéguiner, B. and Bowler, C.J.F.i.M.S. (2018) Competition between silicifiers and non-silicifiers in the past and present ocean and its evolutionary impacts. 5, 22.

Hendry, K.R. and Robinson, L.F. (2012) The relationship between silicon isotope fractionation in sponges and silicic acid concentration: modern and core-top studies of biogenic opal. Geochimica et Cosmochimica Acta 81, 1-12.

Hendry, K.R., Robinson, L.F., McManus, J.F. and Hays, J.D. (2014) Silicon isotopes indicate enhanced carbon export efficiency in the North Atlantic during deglaciation. Nature Communications 5. Hendry, K.R., Robinson, L.F., Meredith, M.P., Mulitza, S., Chiessi, C.M. and Arz, H. (2012) Abrupt changes in high-latitude nutrient supply to the Atlantic during the last glacial cycle. Geology 40, 123126.

Hendry, K.R., Swann, G.E.A., Leng, M.J., Sloane, H.J., Goodwin, C., Berman, J. and Maldonado, M. (2015) Technical Note: Silica stable isotopes and silicification in a carnivorous sponge Asbestopluma sp. Biogeosciences 12, 3489-3498.

Hogg, M., Tendal, O., Conway, K., Pomponi, S., Van Soest, R., Gutt, J., Krautter, M. and Roberts, J. (2010) Deep-seas Sponge grounds: reservoirs of biodiversity. Hooper, J.N. and Van Soest, R.W. (2002) Systema Porifera. A guide to the classification of sponges. Springer.

Horn, M.G., Beucher, C., Robinson, R.S. and Brzezinski, M.A. (2011) Southern Ocean nitrogen and silicon dynamics during the last deglaciation. Earth and Planetary Science Letters 310, 334-339. Howell, K.-L., Piechaud, N., Downie, A.-L. and Kenny, A. (2016) The distribution of deep-sea sponge aggregations in the North Atlantic and implications for their effective spatial management. Deep Sea Research I: Oceanographic Research Papers 115, 309-320.

Howell, K.L., Grehan, A., Piechaud, N., Ross, R., Grassie, A., English, G., NacCarthy, M. and Brereton, R. (2015) Mapping The Deep: The Application Of Predictively Modelled Maps To European Spatial Planning. EUROFLEETS2 Cruise Summary Report RV Celtic Explorer, Cruise No. CE15011. 50pp. Hughes, H.J., Delvigne, C., Korntheuer, M., Jong, J.d., Andre, L. and Cardinal, D. (2011) Controlling the mass bias introduced by anionic and organic matrices in silicon isotopic measurements by MC-ICPMS. Journal of Analytical Atomic Spectrometry 26, 1892-1896.

Hydes, D., Aoyama, M., Aminot, A., Bakker, K., Becker, S., Coverly, S., Daniel, A., Dickson, A., Grosso, O. and Kerouel, R. (2010) Recommendations for the determination of nutrients in seawater to high levels of precision and inter-comparability using continuous flow analysers. GO-SHIP (Unesco/IOC). Jo, B.H., Kim, C.S., Jo, Y.K., Cheong, H. and Cha, H.J. (2016) Recent developments and applications of bioinspired silicification. Korean Journal of Chemical Engineering 33, 1125-1133. Jochum, K., Schuessler, J., Wang, X.H., Stoll, B., Weis, U., Müller, W., Haug, G., Andreae, M. and Froelich, P. (2017) Whole-Ocean Changes in Silica and Ge/Si Ratios During the Last Deglacial Deduced From Long-Lived Giant Glass Sponges. Geophysical Research Letters 44. 
Kenchington, E., Beazley, L.I. and Yashayaev, I. (2016) Hudson 2016-019 International Deep Sea Science Expedition Cruise Report, Canadian Data Report of Fisheries and Aqautic Sciences 1277. Bedford Institute of Oceanography.

Kenchington, E., Power, D. and Koen-Alonso, M. (2013) Associations of demersal fish with sponge grounds on the continental slopes of the northwest Atlantic. Marine Ecology Progress Series 477, 217-230.

Knudby, A., Kenchington, E. and Murillo, F.J. (2013) Modeling the distribution of Geodia sponges and sponge grounds in the Northwest Atlantic. PloS one 8, e82306.

López-Acosta, M., Leynaert, A., Grall, J., Maldonado, M.J.L. and Oceanography (2018) Silicon consumption kinetics by marine sponges: An assessment of their role at the ecosystem level. López-Acosta, M., Leynaert, A., Maldonado, M.J.L. and Oceanography (2016) Silicon consumption in two shallow-water sponges with contrasting biological features. 61, 2139-2150. Maldonado, M., Aguilar, R., Bannister, R.J., Bell, J.J., Conway, K.W., Dayton, P.K., Díaz, C., Gutt, J., Kelly, M. and Kenchington, E.L. (2017) Sponge grounds as key marine habitats: a synthetic review of types, structure, functional roles, and conservation concerns. Marine Animal Forests: The Ecology of Benthic Biodiversity Hotspots, 145-183.

Maldonado, M., Navarro, L., Grasa, A., Gonzalez, A. and Vaquerizo, I. (2011) Silicon uptake by sponges: a twist to understanding nutrient cycling on continental margins. Nature Scientific Reports 1, doi:10.1038/srep00030.

Maldonado, M., Ribes, M. and van Duyl, F.C. (2012) Nutrient fluxes through sponges: biology, budgets, and ecological implications, Advances in marine biology. Elsevier, pp. 113-182. Maldonado, M. and Riesgo, A. (2007) Intra-epithelial spicules in a homosclerophorid sponge. Cell Tissue Research 328, 639-650.

Marron, A.O., Ratcliffe, S., Wheeler, G.L., Goldstein, R.E., King, N., Not, F., De Vargas, C. and Richter, D.J. (2016) The Evolution of Silicon Transport in Eukaryotes. Molecular Biology and Evolution 33, 3226-3248.

Matsumoto, K. and Sarmiento, J.L. (2008) A corollary to the silicic acid leakage hypothesis. Paleoceanography 23, doi:10.1029/2007PA001515.

Milligan, A.J., Varela, D.E., Brzezinski, M.A. and Morel, F.M.M. (2004) Dynamics of silicon metabolism and silicon isotopic discrimination in a marine diatom as a function of $\mathrm{pCO}_{2}$. Limnology and Oceanography 49, 322-329.

Müller, W.E., Schröder, H.C., Burghard, Z., Pisignano, D. and Wang, X. (2013) Silicateins-a novel paradigm in bioinorganic chemistry: enzymatic synthesis of inorganic polymeric silica. Chemistry-A European Journal 19, 5790-5804.

Müller, W.E., Wang, X., Burghard, Z., Bill, J., Krasko, A., Boreiko, A., Schloßmacher, U., Schröder, H.C. and Wiens, M. (2009) Bio-sintering processes in hexactinellid sponges: Fusion of bio-silica in giant basal spicules from $<\mathrm{i}>$ Monorhaphis chuni</i>. Journal of structural biology 168, 548-561. Müller, W.E.G., Schloßmacher, U., Wang, X., Boreiko, A., Brandt, D., Wolf, S.E., Tremel, W. and Schroeder, H.C. (2007) Poly(silicate)-metabolizing silicatein in siliceous spicules and silicasomes of demosponges comprises dual enymatic activities (silica polymerase and silica esterase). FEBS Journal 275, 362-370.

Murillo, F.J., Muñoz, P.D., Cristobo, J., Ríos, P., González, C., Kenchington, E. and Serrano, A. (2012) Deep-sea sponge grounds of the Flemish Cap, Flemish Pass and the Grand Banks of Newfoundland (Northwest Atlantic Ocean): distribution and species composition. Marine Biology Research 8, 842854.

Opfergelt, S., Burton, K.W., Pogge von Strandmann, P.A.E., Gislason, S.R. and Halliday, A.N. (2013) Riverine silicon isotope variations in glaciated basaltic terrains: Implications for the Si delivery to the ocean over glacial-interglacial intervals. Earth and Planetary Science Letters 369-370, 211-219. Reincke, T. and Barthel, D. (1997) Silica uptake kinetics of Halichondria panicea in Kiel Bight. Marine Biology 129, 591-593. 
Reynolds, B.C., Aggarwal, J., Andre, L., Baxter, D., Beucher, C., Brzezinski, M.A., Engstrom, E., Georg, R.B., Land, M., Leng, M.J., Opfergelt, S., Rodushkin, I., Sloane, H.J., van der Boorn, S.H.J.M., Vroon, P.Z. and Cardinal, D. (2007) An inter-laboratory comparison of Si isotope reference materials. Journal of Analytical Atomic Spectrometry 22, 561-568. Rice, A., Thurston, M. and New, A.J.P.i.O. (1990) Dense aggregations of a hexactinellid sponge, Pheronema carpenteri, in the Porcupine Seabight (northeast Atlantic Ocean), and possible causes. 24, 179-196. Riesgo, A., Maldonado, M., López-Legentil, S. and Giribet, G.J.J.o.m.e. (2015) A Proposal for the Evolution of Cathepsin and Silicatein in Sponges. 80, 278-291.

Rousseau, J., Ellwood, M.J., Bostock, H. and Neil, H. (2016) Estimates of late Quaternary mode and intermediate water silicic acid concentration in the Pacific Southern Ocean. Earth and Planetary Science Letters 439, 101-108.

Schrader, H.J. (1972) Anlosung und Konservation von Diatomeenschalen bein Absinken am Beispiel des Landsort-Tiefs in der Ostsee. Nova Hedwigia Beih 39.

Schroeder, H.C., Krasko, A., Le Pennee, G., Adell, T., Wiens, M., H., H., Muller, M. and Muller, W.E.G. (2003) Silicase, an enzyem which degrades biogenous amorphous silica: contribution to the metabolism of silica deposition in the demosponge Suberites domuncula. Prog. Mol. Subcell. Biol. 33, 249-268.

Shimizu, K., Cha, J., Stucky, G.D. and Morse, D.E. (1998) Silicatein a: Cathepsin L-like protein in sponge biosilica. Proceedings of the National Academy of Sciences of the USA 95, 6234-6238. Tabachnick, K., Janussen, D. and Menshenina, L. (2017) Cold biosilicification in Metazoan: Psychrophilic glass sponges, Extreme Biomimetics. Springer, pp. 53-80.

880 Tréguer, P., Bowler, C., Moriceau, B., Dutkiewicz, S., Gehlen, M., Aumont, O., Bittner, L., Dugdale, R., 881 Finkel, Z. and ludicone, D. (2018) Influence of diatom diversity on the ocean biological carbon pump. 882 Nature Geoscience 11, 27.

883 Tréguer, P. and De la Rocha, C.L. (2013) The world ocean silica cycle. Annual Review of Marine 884 Science 5, 477-501.

885 Vacelet, J. (2006) New carnivorous sponges (Porifera, Poecilosclerida) collected from manned submersibles in the deep Pacific. Zoological Journal of the Linnean Society 148, 553-584. Vacelet, J. and Duport, E. (2004) Prey capture and digestion in the carnivorous sponge Asbestopluma hypogea (Porifera: Demospongiae). Zoomorphology 123, 179-190.

Wang, X., Schröder, H.C., Brandt, D., Wiens, M., Lieberwirth, I., Glasser, G., Schloßmacher, U., Wang, S. and Müller, W.E.J.C. (2011) Sponge biosilica formation involves syneresis following polycondensation in vivo. $12,2316-2324$.

Wang, X., Schröder, H.C. and Müller, W.E. (2009) Giant Siliceous Spicules From the Deep-sea Glass Sponge Monorhaphis chuni. International review of cell molecular Biology and Evolution 273, 69115.

Weaver, J.C., Morse, D.E.J.M.r. and technique (2003) Molecular biology of demosponge axial filaments and their roles in biosilicification. 62, 356-367.

Wille, M., Sutton, J., Ellwood, M.J., Sambridge, M., Maher, W., Eggins, S. and Kelly, M. (2010) Silicon isotopic fractionation in marine sponges: a new model for understanding silicon isotopic fractionation in sponges. Earth and Planetary Science Letters, doi:10.1016/j.epsl.2010.1001.1036. Woodward, E. and Rees, A. (2001) Nutrient distributions in an anticyclonic eddy in the northeast Atlantic Ocean, with reference to nanomolar ammonium concentrations. Deep Sea Research Part II: Topical Studies in Oceanography 48, 775-793. 


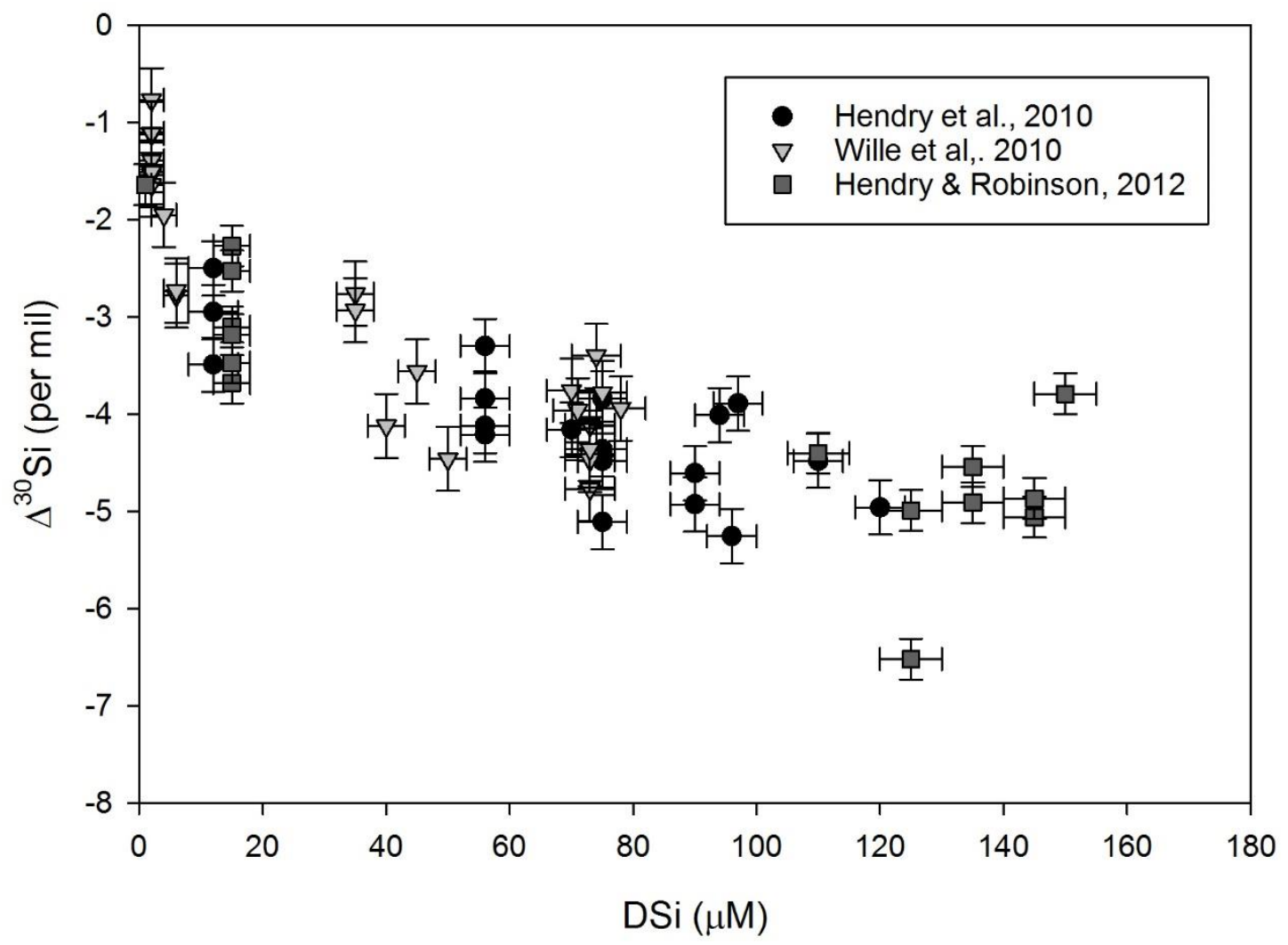

903

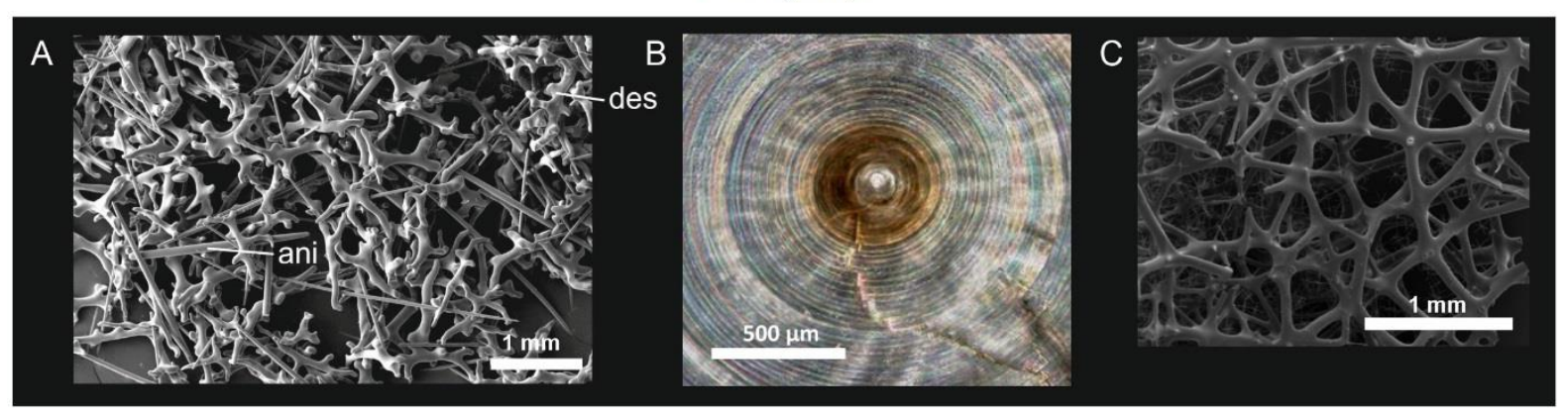




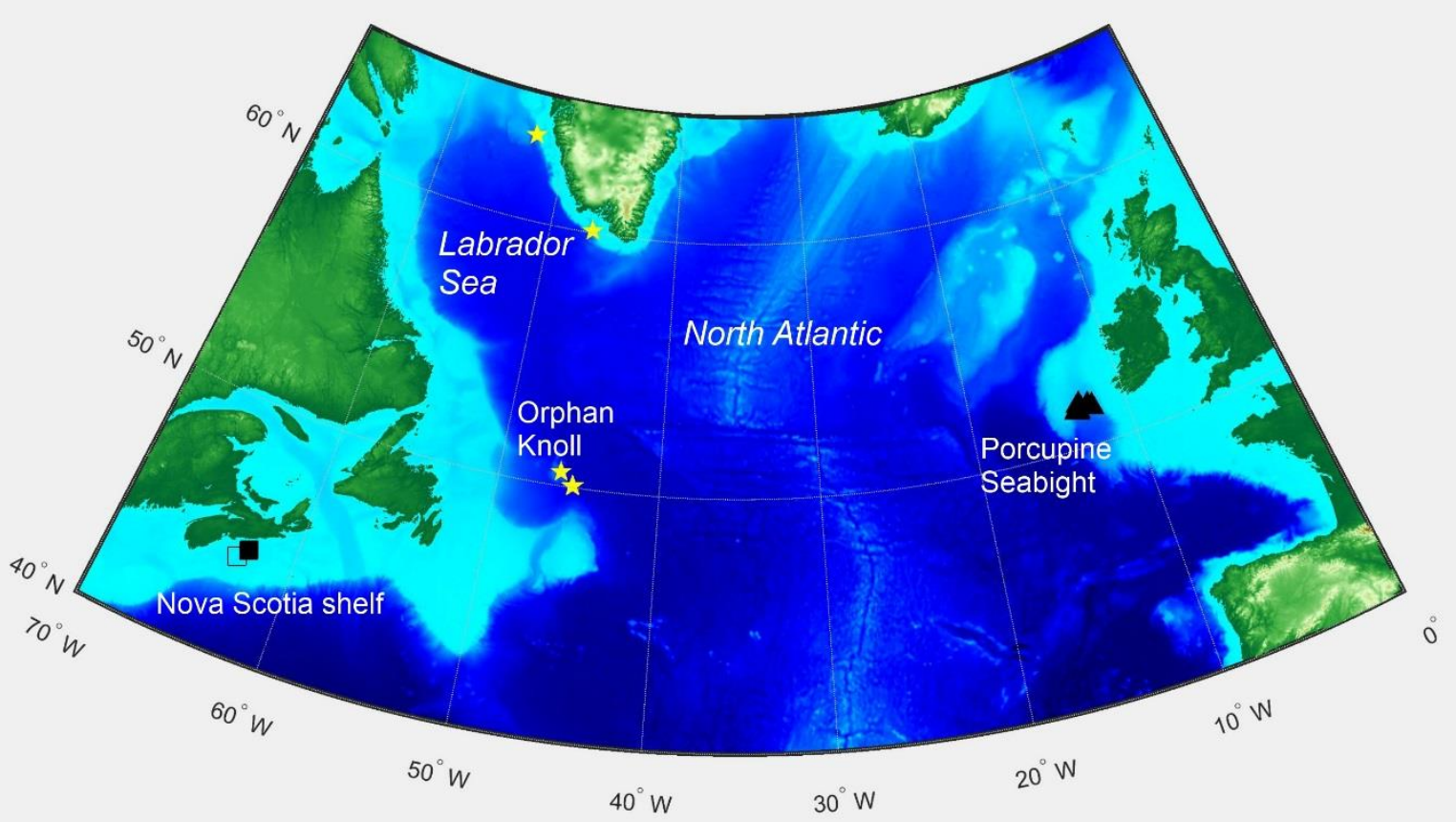

905

906

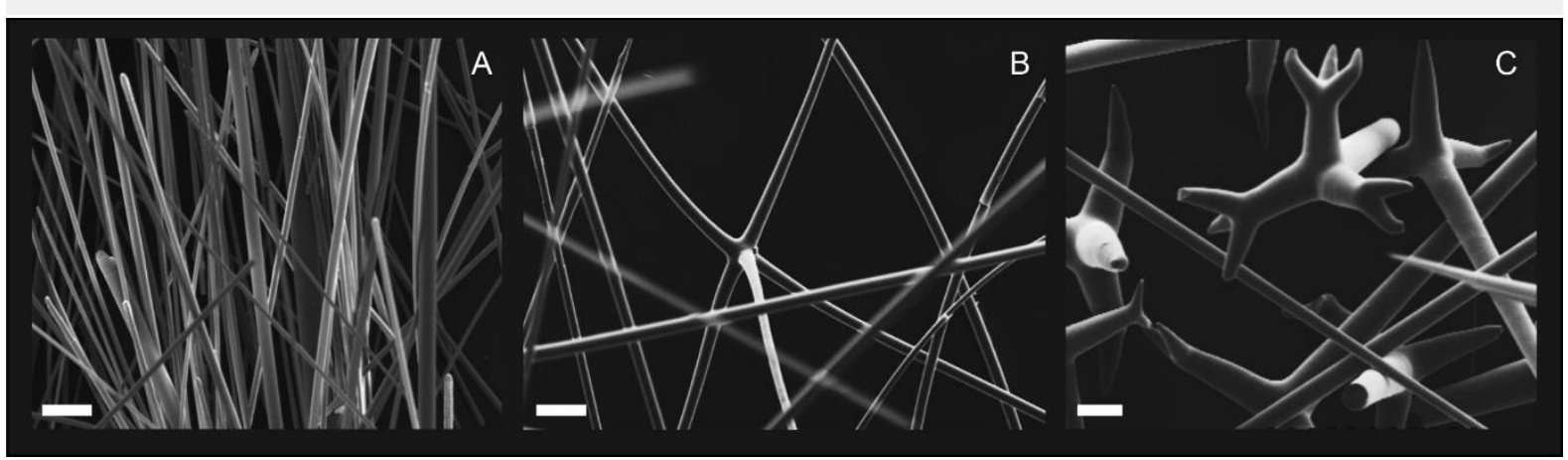






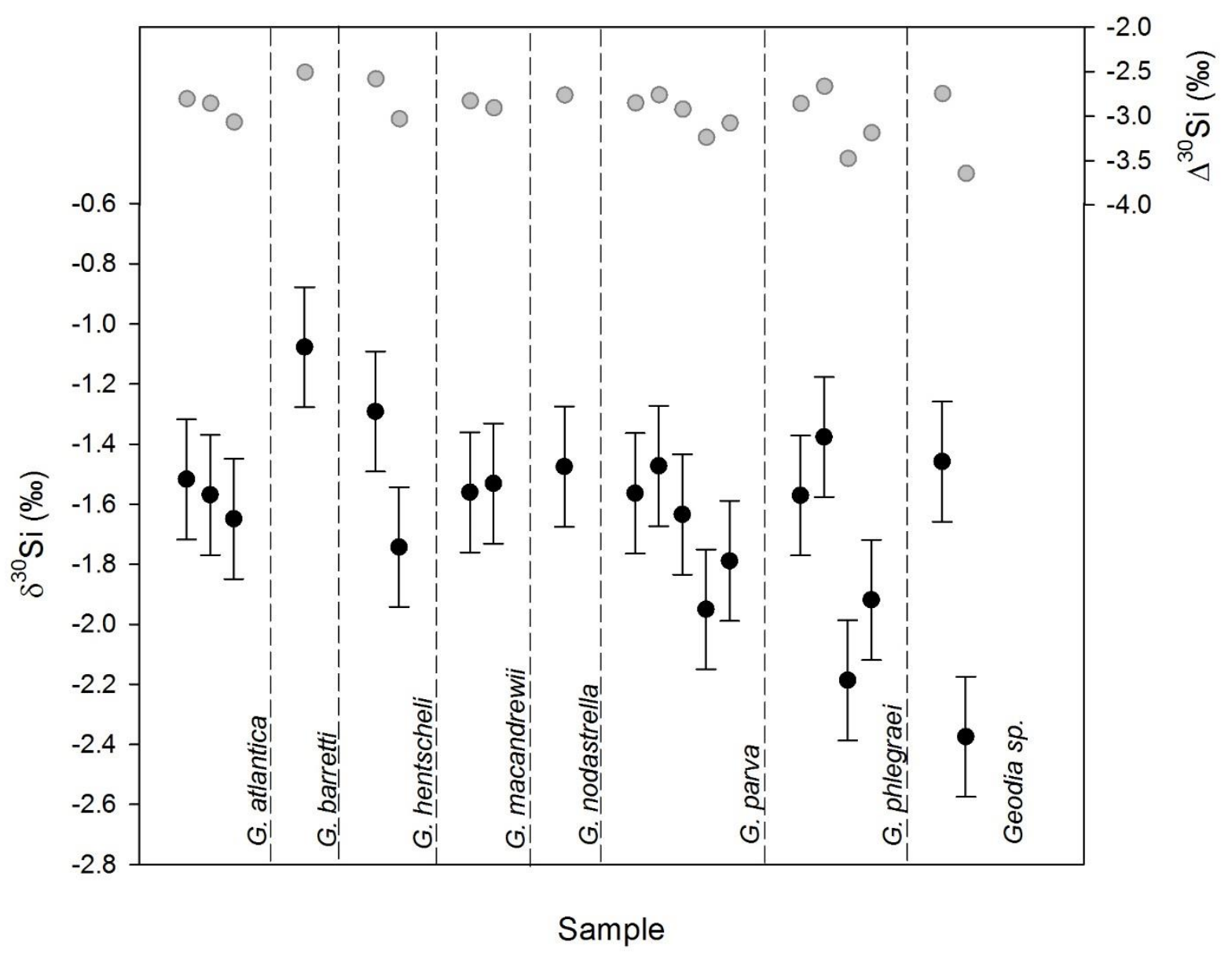



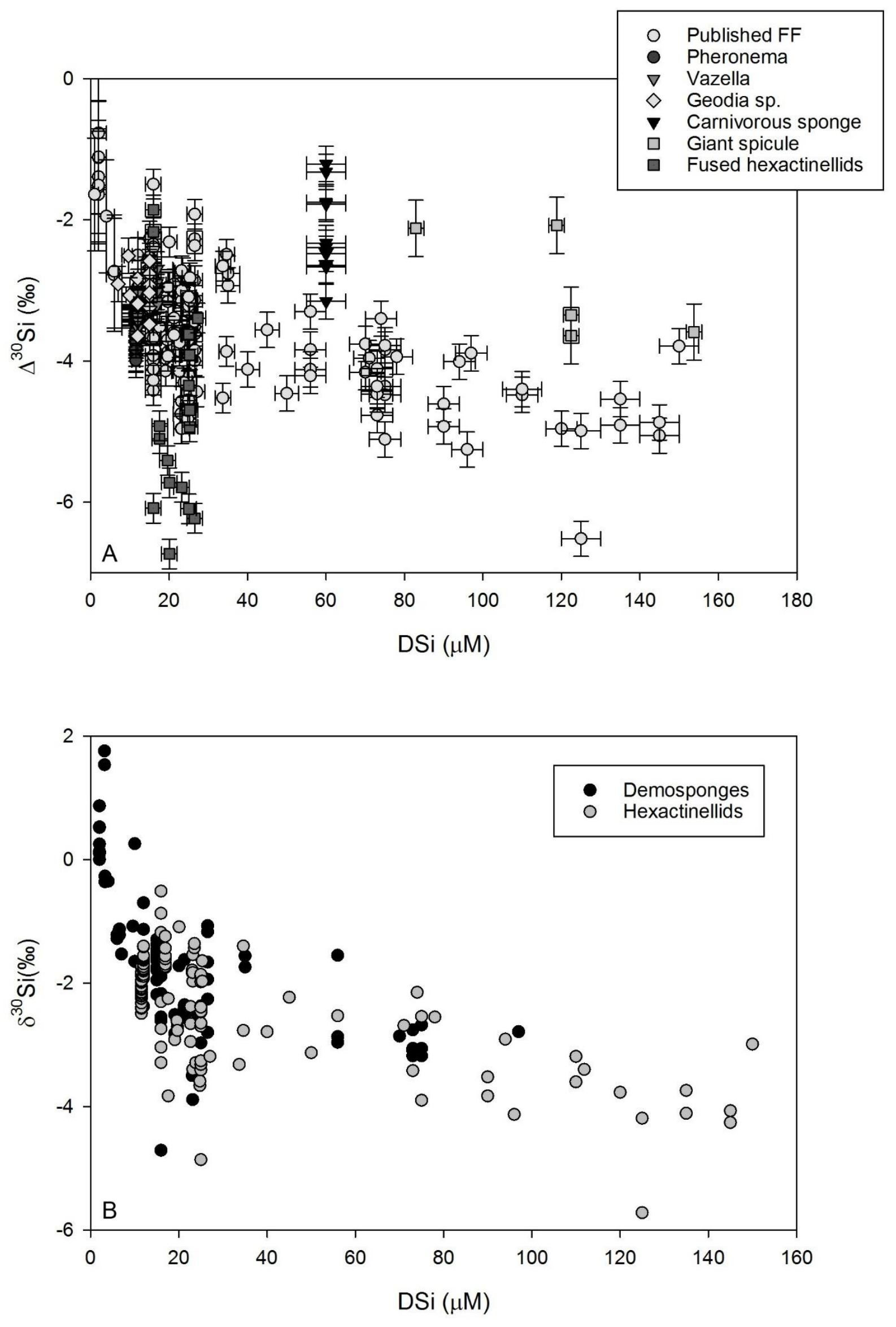


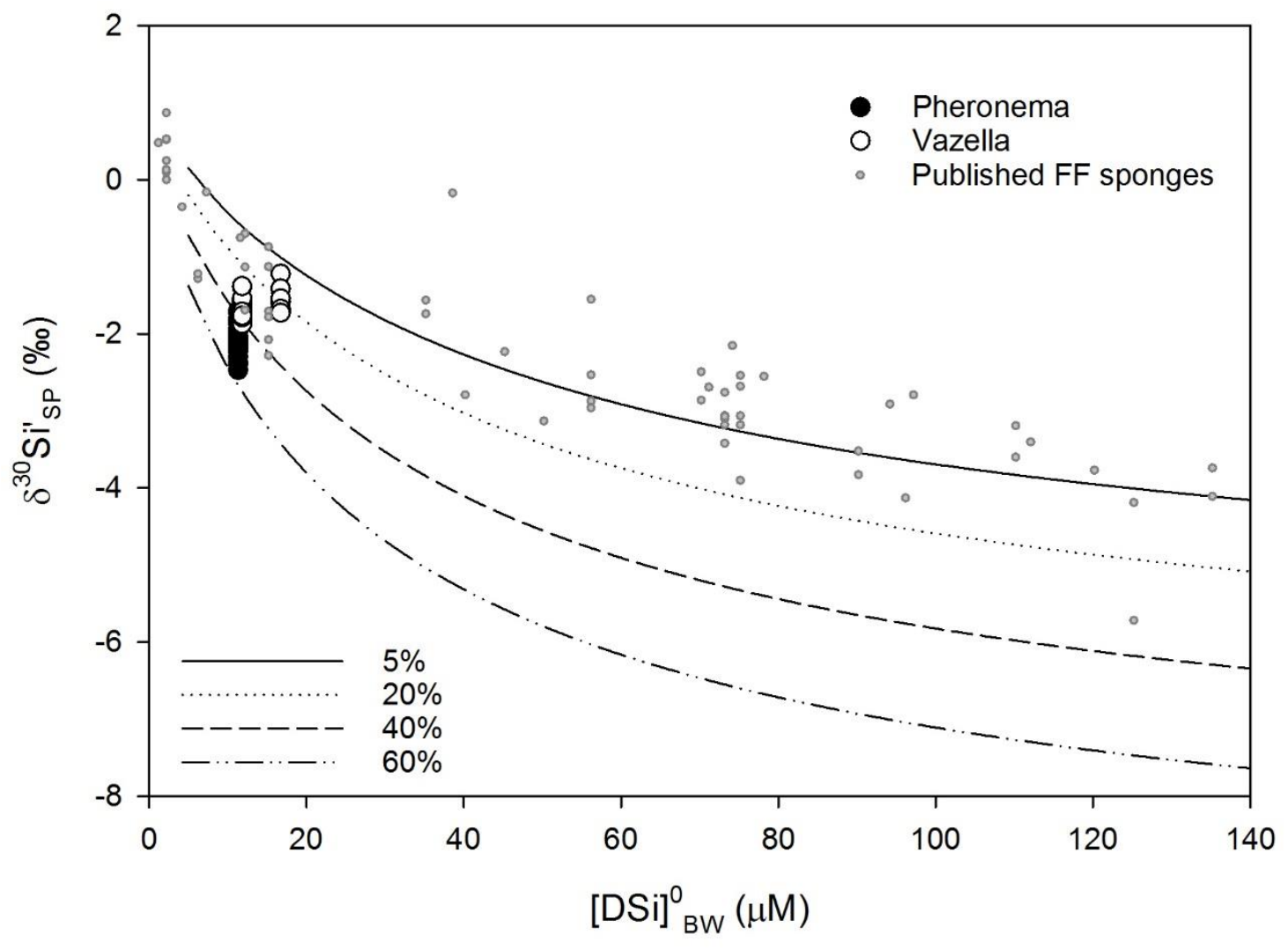

910 

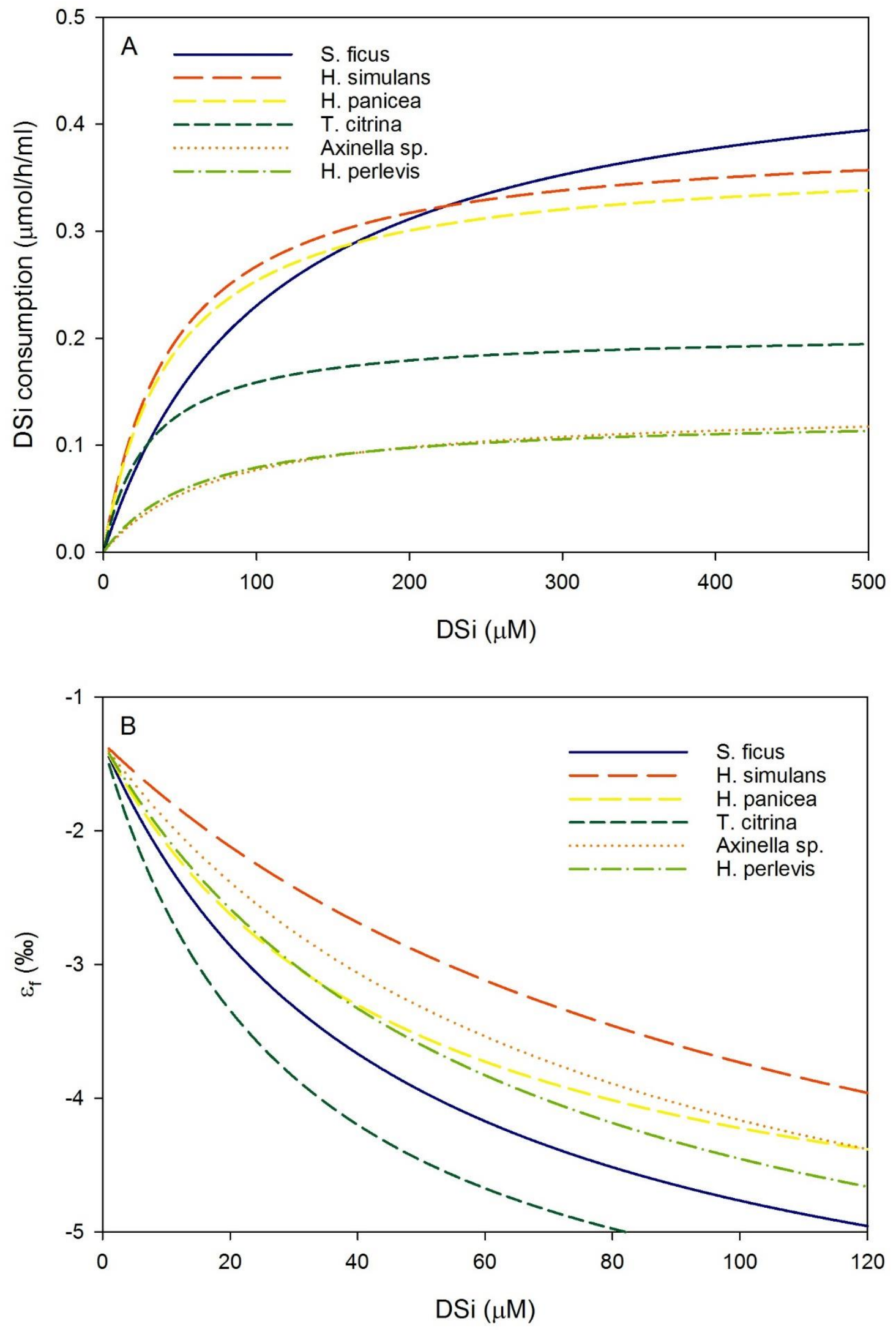